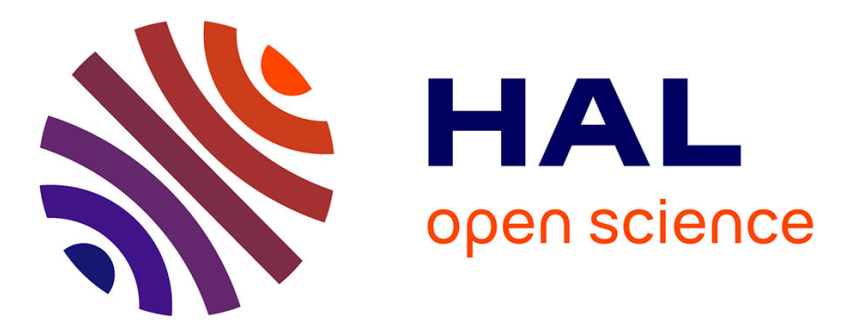

\title{
Impact of glacial erosion on 10 Be concentrations in fluvial sediments of the Marsyandi catchment, central Nepal
}

Vincent Godard, D. W. Burbank, D. L. Bourlès, B. Bookhagen, R. Braucher, G. B. Fisher

\section{To cite this version:}

Vincent Godard, D. W. Burbank, D. L. Bourlès, B. Bookhagen, R. Braucher, et al.. Impact of glacial erosion on 10 Be concentrations in fluvial sediments of the Marsyandi catchment, central Nepal. Journal of Geophysical Research: Earth Surface, 2012, 117 (F3), pp.F03013. 10.1029/2011JF002230 . hal-01537127

\section{HAL Id: hal-01537127 \\ https://hal-amu.archives-ouvertes.fr/hal-01537127}

Submitted on 28 Jun 2017

HAL is a multi-disciplinary open access archive for the deposit and dissemination of scientific research documents, whether they are published or not. The documents may come from teaching and research institutions in France or abroad, or from public or private research centers.
L'archive ouverte pluridisciplinaire HAL, est destinée au dépôt et à la diffusion de documents scientifiques de niveau recherche, publiés ou non, émanant des établissements d'enseignement et de recherche français ou étrangers, des laboratoires publics ou privés. 


\title{
Impact of glacial erosion on ${ }^{10} \mathrm{Be}$ concentrations in fluvial sediments of the Marsyandi catchment, central Nepal
}

\author{
V. Godard, ${ }^{1,2}$ D. W. Burbank, ${ }^{2}$ D. L. Bourlès, ${ }^{1}$ B. Bookhagen, ${ }^{2}$ R. Braucher, ${ }^{1}$ \\ and G. B. Fisher ${ }^{2}$ \\ Received 23 September 2011; revised 28 May 2012; accepted 21 June 2012; published 8 August 2012.
}

[1] Several processes contribute to denudation in high-mountain environments. Of these, glacial erosion is particularly difficult to constrain, despite its critical importance in the evolution of many mountain ranges. In this study, we present a new data set of ${ }^{10} \mathrm{Be}$ concentrations in fluvial sediments sampled along the Marsyandi River and its main tributaries in central Nepal. We interpret the ${ }^{10} \mathrm{Be}$ concentrations as being significantly impacted by glacially derived sediments along the Marsyandi River. Such additions complicate conventional interpretations of ${ }^{10} \mathrm{Be}$-derived catchment-scale denudation rates. Using a simple linear mass-conservation formulation, we invert our data set in order to separate the different denudational contributions to the observed signal, as well as to constrain their magnitude and spatial distribution. Our results suggest significant variations in glacial erosion, both in space and magnitude, within the Marsyandi catchment.

Citation: Godard, V., D. W. Burbank, D. L. Bourlès, B. Bookhagen, R. Braucher, and G. B. Fisher (2012), Impact of glacial erosion on ${ }^{10} \mathrm{Be}$ concentrations in fluvial sediments of the Marsyandi catchment, central Nepal, J. Geophys. Res., 117, F03013, doi:10.1029/2011JF002230.

\section{Introduction}

[2] The rates and processes of glacial erosion are commonly poorly known, and yet they represent a key component of our understanding of the role of glaciers as geomorphological transport agents. The processes of erosion, transport, and deposition acting in glacial landscapes have far-reaching implications for the morphology and dynamics of mountain ranges, as well as for the sediment-flux budget. Indeed, one of the most provocative ideas that has emerged in the field of geodynamics during the last 25 years is that tectonics, denudation, and climate in actively deforming areas may be strongly coupled [Molnar and England, 1990; Raymo and Ruddiman, 1992; Avouac and Burov, 1996; Willett, 1999; Thiede et al., 2004; Whipple and Meade, 2006; Godard et al., 2009]. This proposed coupling has been the focus of numerous numerical and field studies and, because glaciers have been argued to be highly effective erosion agents [Hallet et al., 1996; Koppes and Hallet, 2006; Foster et al., 2008], the magnitude and role of glacial erosion has quickly moved to the forefront of this field [Herman and Braun, 2006; Anderson et al., 2006; Brocklehurst and Whipple, 2006; Tomkin, 2007; Tomkin and Roe, 2007; Brocklehurst and Whipple, 2007;

\footnotetext{
${ }^{1}$ Aix-Marseille Université, CNRS, IRD, CEREGE UM34, Aix en Provence, France.

${ }^{2}$ Earth Research Institute, University of California, Santa Barbara, California, USA.

Corresponding author: V. Godard, Aix-Marseille Université, CNRS, IRD, CEREGE UM34, F-13545 Aix en Provence, France. (godard@cerege.fr)

(C)2012. American Geophysical Union. All Rights Reserved. 0148-0227/12/2011JF002230
}

Berger et al., 2008; Egholm et al., 2009; Koppes and Montgomery, 2009; Foster et al., 2010; Godard and Burbank, 2011; Ward and Anderson, 2011]. Nonetheless, our understanding of the glacial components of the landscape still lags behind that of the widely studied fluvial domain, and numerous debates persist concerning basic aspects of glacial processes and behavior [Rahaman et al., 2009; Thomson et al., 2010]. Among the gaps in our knowledge regarding the dynamics of modern glaciers, one of the most critical is the lack of simple, systematic, field-based methodologies for the quantification of glacial erosion. This gap is particularly noticeable in the context of the much wider success in quantifying river incision and hillslope erosion [e.g., von Blanckenburg, 2005]. Here, we present a methodology and associated results that try to fill this gap and quantify spatially variable glacial erosion.

[3] The development of physically based and quantitative models for glacial erosion processes [Boulton, 1979; Hallet, 1979; Boulton, 1996; Hallet, 1996] has paved the way for the investigation of the influence of glaciers at the scale of the whole landscape [Tomkin, 2007; Jamieson et al., 2008; Herman and Braun, 2008; MacGregor et al., 2009; Egholm et al., 2009]. On the other hand, small-scale field studies have observed glacier-bed processes such as quarrying [Anderson et al., 1982; Rea and Whalley, 1994; Cohen et al., 2006]. Such studies provide invaluable insights about instantaneous glacial morphogenetic activity, but their limited spatial extent does not permit reliable generalization to an integrated estimate of the efficiency of glaciers at the scale of the whole landscape. In contrast, several studies have investigated the sediment budget of glacier-fed streams or basins to derive large-scale estimates of glacial erosion. 


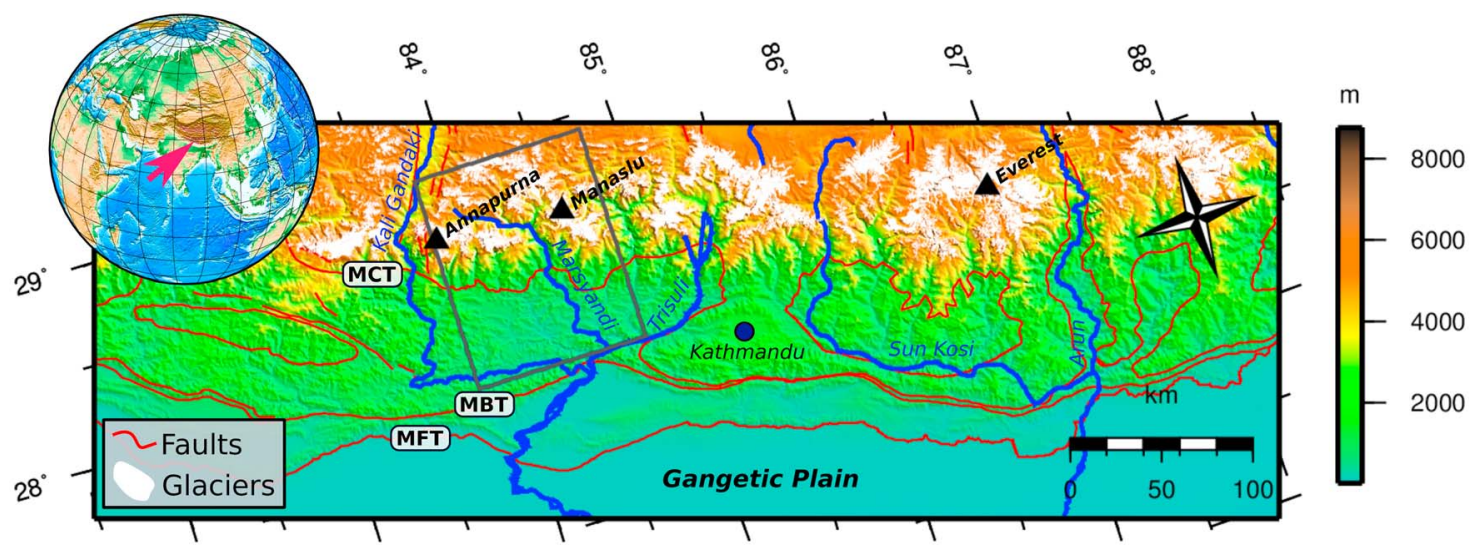

Figure 1. Location map for the Himalayas of central Nepal showing the main topographical, fluvial and tectonic features. White areas represent modern glaciers [Armstrong et al., 2005]. MCT: Main Central Thrust, MBT: Main Boundary Thrust, MFT: Main Frontal Thrust. Dark gray box indicates the position of Figure 2.

These reconstructions, however, require very good preservation of sediment records, which is not common in many contexts [Small et al., 1984; Riihimaki et al., 2005; Staiger et al., 2006; Koppes and Hallet, 2006; Dowdeswell et al., 2010].

[4] The purpose of the work presented in this article is to contribute to the development of tools and approaches that allow the estimation of glacial erosion in mountainous regions. We build on the growing number of studies analyzing catchment-scale denudation rates through concentrations of cosmogenic nuclides in river sediments and derive a simple mass-conservation approach to deconvolve the respective contributions to denudation of the glacial and fluvial systems. Our study is focused on the Marsyandi catchment in central Nepal, where previous investigations have yielded a dense data set and offer robust and detailed documentation of climatic, geomorphological and tectonic processes [Pratt et al., 2002; Harper and Humphrey, 2003; Searle and Godin, 2003; Gabet et al., 2004a, 2004b; Pratt-Sitaula et al., 2004; Brewer et al., 2006; Huntington et al., 2006; Huntington and Hodges, 2006; Blythe et al., 2007; Craddock et al., 2007; Garzanti et al., 2007; Pratt-Sitaula et al., 2007; Whipp et al., 2007; Gabet et al., 2008, 2010].

\section{Setting}

[5] We present here selected features of the Himalayas of central Nepal and the Marsyandi river to provide the background of our study (Figures 1 and 2). Further information about the broader geological context of the area can be found in Hodges [2000], Avouac [2003] and Yin [2006].

\subsection{Geological, Morphological and Climatological Context}

[6] From the low-elevation Gangetic plain to the 5-kmhigh Tibetan Plateau, the Himalaya stands as one of the steepest topographic escarpments on Earth (Figure 1). The most salient morphological feature of the range in central Nepal is a major topographic break often referred to as the physiographic transition $\left(\mathrm{PT}_{2}\right)$ [Harrison et al., 1998; Hodges et al., 2001; Wobus et al., 2003], which marks the beginning of the high range front. In the Marsyandi area, this transition also approximately corresponds to the geological boundary between the Lesser and Greater Himalayas that is associated with the crossing of the Main Central Thrust (MCT). South of this transition, the Lesser Himalaya is dominated by mostly Precambrian metasediments, the average elevation ranges from 1 to $2 \mathrm{~km}$, and the landscape is characterized by moderate denudation $(\sim 1 \mathrm{~mm} / \mathrm{yr})$ [Lavé and Avouac, 2001; Pratt-Sitaula et al., 2004; Bollinger et al., 2004].

[7] In contrast, the average elevation starts to rise abruptly north of the $\mathrm{PT}_{2}$ when entering the crystalline units of the Greater Himalaya that are actively uplifted above the crustal ramp of the Main Himalayan Thrust [Avouac, 2003]. This abrupt mountain front has a first-order impact on the regional climate, the most notable of which is the development of a strong orographic effect and intense precipitation focused on the transition between the Lesser and Greater Himalayas, with rainfall up to $4 \mathrm{~m} / \mathrm{yr}$ [Bookhagen et al., 2005; Bookhagen and Burbank, 2006; Andermann et al., 2011; Bookhagen and Burbank, 2010]. Given both greater rainfall and steeper slopes, denudation rates are significantly higher in the Greater Himalaya (3-6 mm/yr) when compared to those observed south of the transition [Lavé and Avouac, 2001; Blythe et al., 2007].

[8] Farther north, the Tethyan series are the dominant lithologies, which comprise successions of Mesozoic and Paleozoic sediments [Searle and Godin, 2003]. Marking the southern edge of the Tibetan Plateau, this region lies in the Himalayan rainshadow and is significantly drier. For example, in the Marsyandi catchment, a five- to ten-fold difference in monsoon precipitation exists between the wet southern front of the range and the northernmost areas that lie within the rainshadow [Burbank et al., 2003; Craddock et al., 2007]. This climatological contrast is reflected in the denudation rates that decrease gradually northward to $<1 \mathrm{~mm} / \mathrm{yr}$ [Lavé and Avouac, 2001; Garzanti et al., 2007; Gabet et al., 2008]. It is suspected that denudation in the high range is modulated in time by the expansion and retreat of glaciers, following long-term climatic fluctuations [Gabet et al., 2008].

[9] Another important climatic feature of the Himalayan range is that precipitation is not distributed evenly across the 


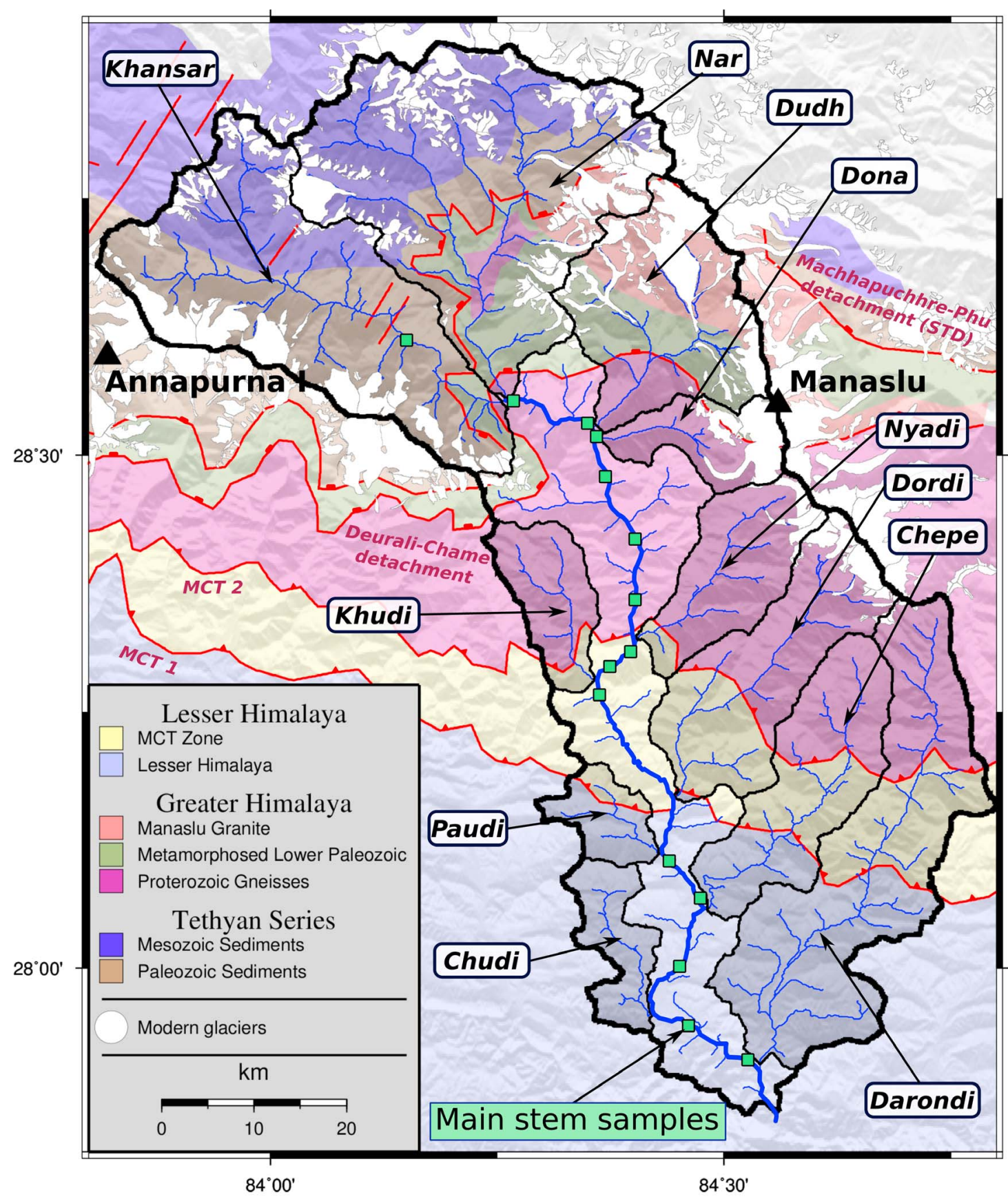

Figure 2. Geological map of the Marsyandi catchment. See Figure 1 for broader location context. Geological units are from Searle and Godin [2003]. White areas represent modern glaciers [Armstrong et al., 2005]. The thick blue line indicates the Marsyandi main trunk. The Khansar is actually the upper Marsyandi. Green squares are locations of the samples from the Marsyandi main trunk. The main sub-catchments used in this study are indicated by darker shading. These sub-catchments were sampled at their confluence with the main trunk.

year, but is strongly concentrated during the monsoon season, in particular in Nepal where more than $80 \%$ of the annual precipitation occurs between the months of May and October [Bookhagen, 2010; Bookhagen and Burbank, 2010].

\subsection{Denudation of the Marsyandi Catchment}

[10] The Marsyandi catchment is of particular interest for the study of erosional processes in orogenic settings due to several geomorphological investigations over the past decade that have helped delineate the spatiotemporal distribution of denudation with a level of detail that is unmatched in any similar environment (Figure 2). These earlier studies have, in particular, improved our understanding of several important processes pertaining to the interactions between precipitation and denudation [Burbank et al., 2003; Gabet et al., 2004b, 2004a; Bookhagen and Burbank, 2006; Craddock et al., 
2007], the nature of fluvial incision in actively uplifting domains [Lavé and Avouac, 2001; Pratt-Sitaula et al., 2004], the dynamics of sediment transport in mountain rivers over several time-scales [Garzanti et al., 2007; Pratt-Sitaula et al., 2007; Gabet et al., 2008], and the long-term denudation and kinematics of orogenic wedges seen through thermochronometry [Huntington and Hodges, 2006; Huntington et al., 2006; Brewer et al., 2006; Blythe et al., 2007; Whipp et al., 2007].

[11] One specific aspect of denudation that has received less attention is the erosion associated with ice flow. Previous work in the Marsyandi catchment has delineated some aspects of the past extension of glaciers, and in particular ELA depression [Duncan et al., 1998; Harper and Humphrey, 2003; Burbank et al., 2003; Pratt-Sitaula, 2005; Pratt-Sitaula et al., 2011], and locally estimated rates of glacier headwall retreat [Heimsath and McGlynn, 2008]. Although glaciers still occupy a significant portion of the catchment area $(\sim 15 \%)$, the fraction of total landscape denudation that can be attributed to glacial erosion remains largely unquantified in this region. The quantification of the contribution of glacial erosion to the total denudation budget is of particular interest in the Marsyandi area because some recent results have suggested that denudation may have been highly variable through time in the higher Himalaya. Modern denudation rates suggest that the wet southern flank of the range is experiencing faster denudation than the northern drier areas [Brewer et al., 2006; Garzanti et al., 2007; Gabet et al., 2008]. Longer term estimates of denudation based on fission track dates across the same area do not show a pronounced north-south gradient in denudation [Burbank et al., 2003; Blythe et al., 2007; Whipp et al., 2007], such that exhumation appears to be largely decoupled from the precipitation pattern. In contrast, new $\mathrm{U}-\mathrm{Th} / \mathrm{He}$ ages in relief transects suggest mean denudation rates at $10^{5}-10^{6} \mathrm{yr}$ timescales that are significantly lower in the rain shadow than on the southern flank of the Greater Himalaya [Streit et al., 2011]. Until the differences between the fission track and $\mathrm{U}-\mathrm{Th} / \mathrm{He}$ dates are resolved, the possibility remains that denudation was higher during glacial periods than during interglacials in the northern dry part of the catchment. Such a contrast could lead to long-term rates that are on par with those seen farther south [Gabet et al., 2008].

\section{Methods and Data}

\subsection{Cosmogenic Nuclides in River Sands}

[12] Over the last 15 years, the measurement of cosmogenic nuclide concentrations in river sands has been found to be one of the most efficient ways to quantify catchmentaveraged denudation [Brown et al., 1995; Bierman and Steig, 1996; Granger et al., 1996; Schaller et al., 2001; Vance et al., 2003; von Blanckenburg, 2005; Wittmann et al., 2007; Ouimet et al., 2009; Godard et al., 2010; DiBiase et al., 2010]. If the size of the sampled catchment is large enough to ensure an appropriate representation of the surface processes acting over the integration timescale [Niemi et al., 2005; Yanites et al., 2009], this method delivers information on denudation that is both spatially averaged over the catchment and temporally averaged over the time required to erode to a depth equivalent to the characteristic attenuation length of cosmic rays ( $\sim 60 \mathrm{~cm}$ in bedrock).
[13] It should be noted that in most situations the observed

${ }^{10} \mathrm{Be}$ concentration in river sediments is used to estimate an average denudation rate for the catchment as a whole, which can be compared with other basin-averaged observations, such as relief, slope or precipitation, in order to test geomorphological models or concepts [e.g., Safran et al., 2005; Ouimet et al., 2009; DiBiase et al., 2010; Bookhagen and Strecker, 2012]. Another way to use such data is to express the observed ${ }^{10} \mathrm{Be}$ concentration as the combined contribution of the different denudation processes occurring across the landscape though a mass-conservation budget [Bierman and Steig, 1996; Perg et al., 2003; Nichols et al., 2005; Belmont et al., 2007]. This approach requires explicit hypotheses on the nature of surface processes acting inside the catchment (i.e. proposing analytical formulations for fluvial or hillslope denudation rates) in order to derive the volume and concentration of sediments produced at every point of the landscape. Such formulations allow predictions to be made on ${ }^{10} \mathrm{Be}$ concentrations that can then be compared with observations to test the underlying hypotheses and associated parameters [Gayer et al., 2008; Delunel et al., 2010]. Our study relies on this type of approach to attempt to retrieve information on the glacial processes occurring inside the sampled catchments.

\subsection{Sampling Strategy and Processing}

[14] We measured the ${ }^{10} \mathrm{Be}$ concentration in 27 samples that were collected over two field seasons in 1997 (sampling by Brewer et al. [2006] and processing in this study) and 2009. The sampling strategy was designed to allow a dense along-stream coverage from the lower part of the Marsyandi River near its confluence with the Trisuli to the upper part of the catchment. Major tributaries were also sampled near their confluence with the trunk stream. This dense spatial coverage allows us to obtain a high-resolution picture of the variations of the ${ }^{10} \mathrm{Be}$ concentrations in river sands across the catchment. Furthermore, the joint analysis of samples collected during two distinct field campaigns more than 10 years apart permits us to assess the time variability of the ${ }^{10} \mathrm{Be}$ concentration at similar positions along the river. Extensive data presentation and details of the analytical procedures are provided in the auxiliary material. ${ }^{1}$

\subsection{Evolution of the ${ }^{10} \mathrm{Be}$ Signal Across the Marsyandi Catchment}

[15] Striking variability is present in the ${ }^{10} \mathrm{Be}$ concentration along the Marsyandi main trunk and its dominant tributaries (Figure 3). Along the main channel, the general tendency is that the samples from the highest (Tethyan) parts of the catchment yield relatively higher ${ }^{10} \mathrm{Be}$ concentrations ( 15,000 at/g), and concentrations progressively decrease (down to $\sim 7,000 \mathrm{at} / \mathrm{g}$ ) as the river traverses, first, the Greater Himalaya and then the northern half of the Lesser Himalaya. Within the southern half of the Lesser Himalaya, cosmogenic radionuclide $(\mathrm{CRN})$ concentrations reveal a secondary increasing trend in the downstream direction.

[16] The distribution of ${ }^{10} \mathrm{Be}$ concentrations from the tributaries is less systematic than for samples from the main trunk. Tributaries that drain the Greater Himalaya have

\footnotetext{
${ }^{1}$ Auxiliary materials are available in the HTML. doi:10.1029/ 2011JF002230
} 


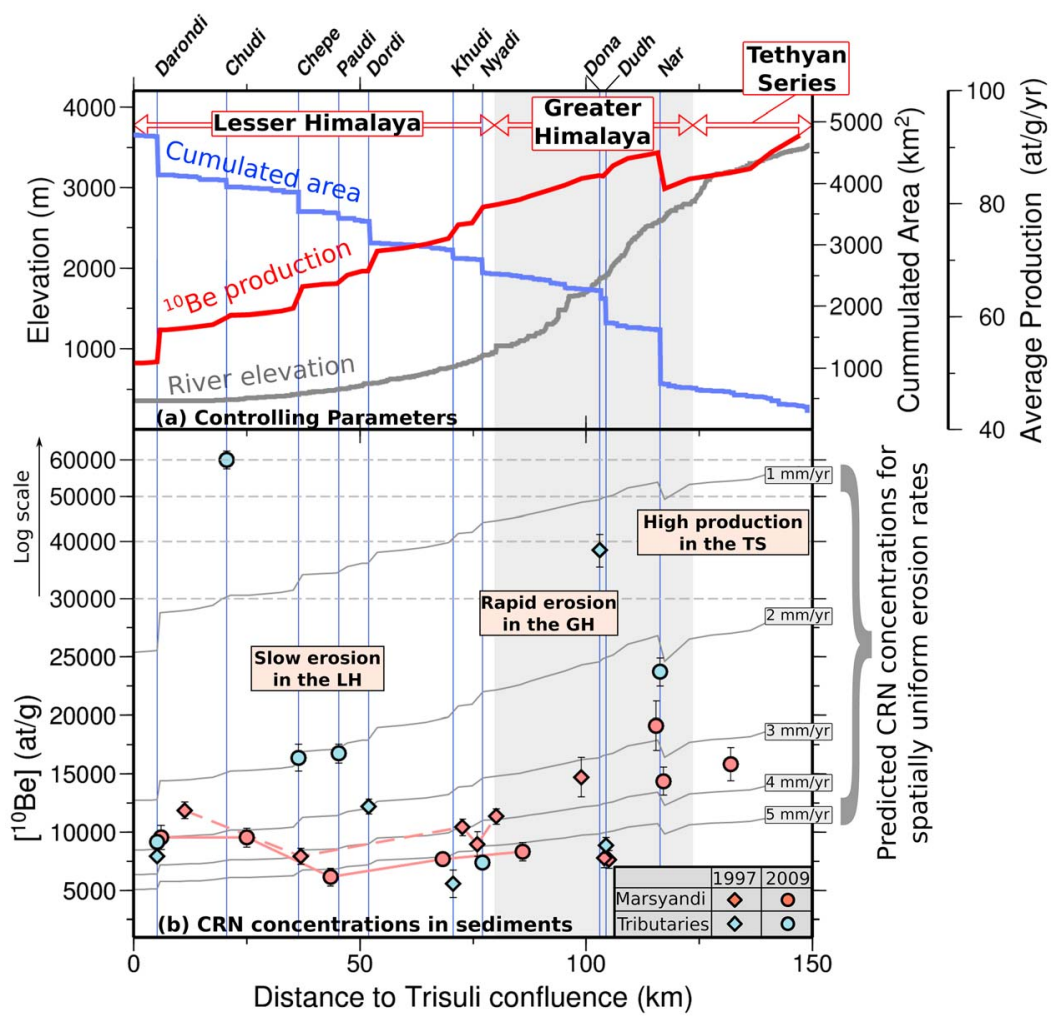

Figure 3. (a) Channel profile of the Marsyandi (dark gray) with corresponding contributing area (blue) and basin-averaged production of ${ }^{10} \mathrm{Be}(\mathrm{red})$. (b) Evolution of the ${ }^{10} \mathrm{Be}$ signal along the Marsyandi river and its main tributaries (light red and blue filled symbols respectively). Error bars are $\pm 1 \sigma$ uncertainties. Circles and diamonds indicate whether the samples were collected in 2009 or 1997, respectively. The red solid and dashed lines are connecting the samples from the lower reach of the Marsyandi, that were collected in 2009 or 1997, respectively. Note that the vertical scale changes above $30000 \mathrm{at} / \mathrm{g}$ and becomes logarithmic. The thin gray curves indicate the theoretical evolution of the along-stream ${ }^{10} \mathrm{Be}$ concentration under the hypothesis that the entire Marsyandi catchment is eroding uniformly (1, 2, 3, 4 and $5 \mathrm{~mm} / \mathrm{yr})$ without taking into account any shielding by glaciers.

relatively low concentrations, with the notable exception of the Dona Khola (Figure 3). High variability is also present for the tributaries that join the Marsyandi in its lower reaches, with tributaries that drain exclusively the Lesser Himalaya (Paudi and Chudi) showing the highest concentrations (Figure 3). We observe a relatively good repeatability of the measured concentrations over the two sampling campaigns for both the main trunk and tributaries [Ruhl and Hodges, 2005]. For example, there is less than $15 \%$ relative variation between the two samples collected at the outlet of the Darondi catchment. For samples from the lower reach of the Marsyandi, where the sample density is highest, data from the two periods delineate the same trend as seen in Figure $3 b$.

\subsection{Qualitative Interpretation of the Along-Stream Pattern}

[17] Several factors can potentially account for the evolution of the observed ${ }^{10} \mathrm{Be}$ concentrations along the Marsyandi River. First, given the $5.5-\mathrm{km}$ range in altitude that encompasses $>90 \%$ of the Marysandi catchment, nuclide production rates are $>20$ times higher in the upper reaches of the catchment compared to the lower reaches (Figure $4 b$ ). Second, areas of rapid denudation have lower CRN concentrations because bedrock resides for a shorter amount of time in the high-productivity zone directly below the eroding surface. Given these influences on nuclide concentrations, the high concentration observed in the northernmost part of the catchment could be attributed to the constructive combination of high production rates and relatively slow denudation. Starting from this northernmost part of the catchment and moving downstream, the significant diminution in ${ }^{10} \mathrm{Be}$ concentrations in the Marsyandi sands may result from both lower productivity (due to lower altitude) and faster denudation of Greater Himalayan rocks. Finally, ${ }^{10} \mathrm{Be}$ concentrations stabilize and even begin to increase due to the addition of sediments derived from the Lesser Himalaya lowlands that have low ${ }^{10} \mathrm{Be}$ production rates but also slow denudation, such as the landscapes drained by the Chudi and Paudi rivers (Figure 2).

[18] Another potentially significant factor to consider is the role of glaciers, because they both shield the bedrock from nuclide production by cosmic rays and produce sediments through basal erosion of bedrock that have generally very low CRN content. Because we suspect that glacially derived sediments may significantly contribute to the spatial trends of the ${ }^{10} \mathrm{Be}$ concentration in our data set, we use caution when discussing our results in terms of denudation 


\section{(a) Altitude}

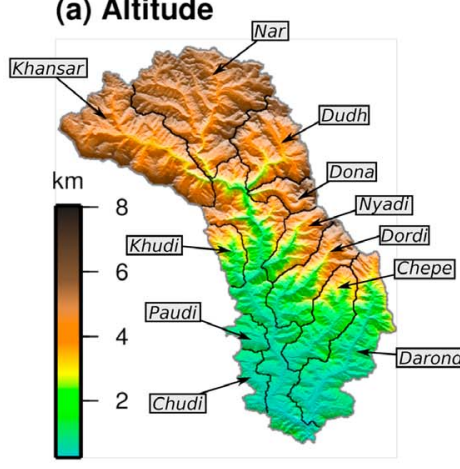

(d) Geomorphic domains

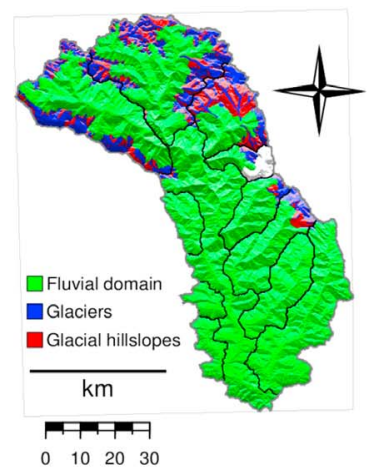

(b) Spallogenic production

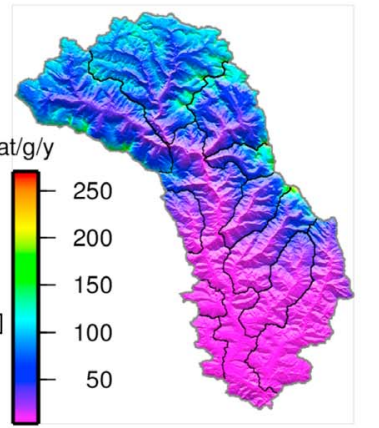

(e) Stream power

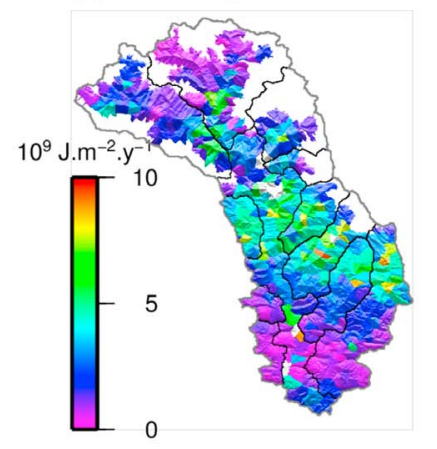

(c) Mean precipitation

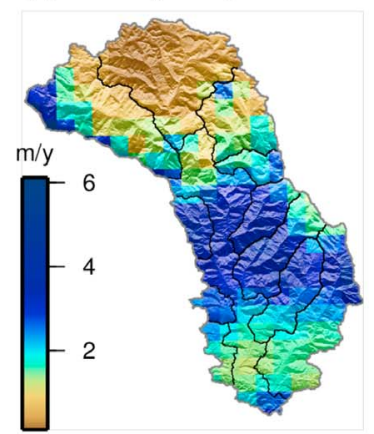

(f) Hillslope angle

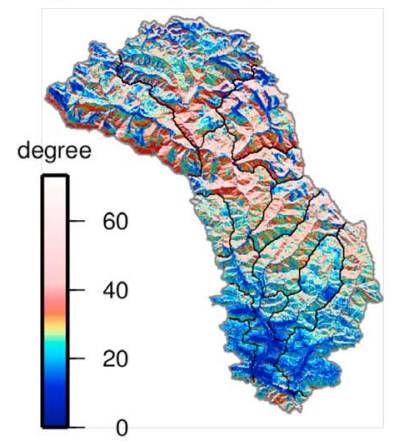

Figure 4. Available data sets over the Marsyandi catchment used as inputs to derive estimates of glacial erosion. (a) Topography of the catchment and location of the sub-catchments considered in this study. (b) Surface production rate for ${ }^{10} \mathrm{Be}$ due to spallogenic contribution [Stone, 2000], corrected for topographic shielding [Dunne et al., 1999] and snow cover with the snow water equivalent data of Bookhagen and Burbank [2010] and the formulation of Gosse and Phillips [2001]. Both shieldings appear to have a low impact on the effective production rates. Note that the production rates used in the calculations presented in this paper also account for the muonic contribution [Braucher et al., 2003, 2011] (see auxiliary material for further information). (c) Average annual precipitation over the catchment [Bookhagen and Burbank, 2010]. (d) Distribution of the main geomorphic domains considered in the mass balance approach (equation (1) and see text for details). The upper part of the Dona catchment is separated from the lower part by a pro-glacial lake which is trapping sediments (see auxiliary material). The glacial hillslope domain is defined as all the areas of the landscape that are directly draining toward the glaciers. (e) Spatially averaged specific stream power using precipitation-based discharge. (f) Topographic slope.

rates. In order to get an estimate of the influence of the glacial sediment input on the ${ }^{10} \mathrm{Be}$ concentrations, we start from the null hypothesis that glacial erosion makes no contribution to the sediment flux, and we calculate, for each sample, an apparent denudation rate that takes only into account the fluvial part of the landscape (i.e., we restrict the calculation of the averaged production rate to the fluvial domain, Figure 4d). We compare this apparent rate with the corresponding catchment-averaged specific stream power (Figure 5). The channel slope and accumulation area used in specific stream-power calculations (Figure 4e) are obtained from a $90-\mathrm{m}$ resolution SRTM DEM. Discharge, $Q$, is obtained from the mean annual precipitation and snowmelt data of Bookhagen and Burbank [2010] (Figure 4c), channel width, $W$, is scaled as $W \alpha Q^{0.4}$ [Burbank et al., 2003; Craddock et al., 2007] and channel slope is calculated along the steepest descent path. This scenario is equivalent to making the assumption that the glaciers and hillslopes connected to them (Figure 4d) are not contributing sediments. Using these assumptions, we observe that the unglaciated tributaries (that we identify as catchments with $<10 \%$ of their area covered by ice) define a roughly linear relationship between denudation rate and specific stream power (gray diamonds, Figure 5a). Lesser Himalayan catchments, such as the Paudi and the Chudi, with high ${ }^{10} \mathrm{Be}$ concentrations and low specific stream-power, define the lower end of this trend. In contrast, the catchments that have more glacial cover almost always plot above this trend (18 out of 19 catchments in Figure 5a) by showing higher apparent denudation than what would be expected for a given specific stream power, with the exception of the Dona and Dordi catchments. We interpret these large positive deviations as the direct manifestation of the dilution of the ${ }^{10} \mathrm{Be}$ signal by glacial sediment input, a dilution leading to a higher apparent denudation rate for a given specific streampower value.

[19] In order to isolate the factors controlling this dilution, we examine the amplitude of the deviation from the baseline defined by the unglaciated catchments (residual in Figures $5 \mathrm{~b}-5 \mathrm{e}$ ) as a function of parameters related to the 


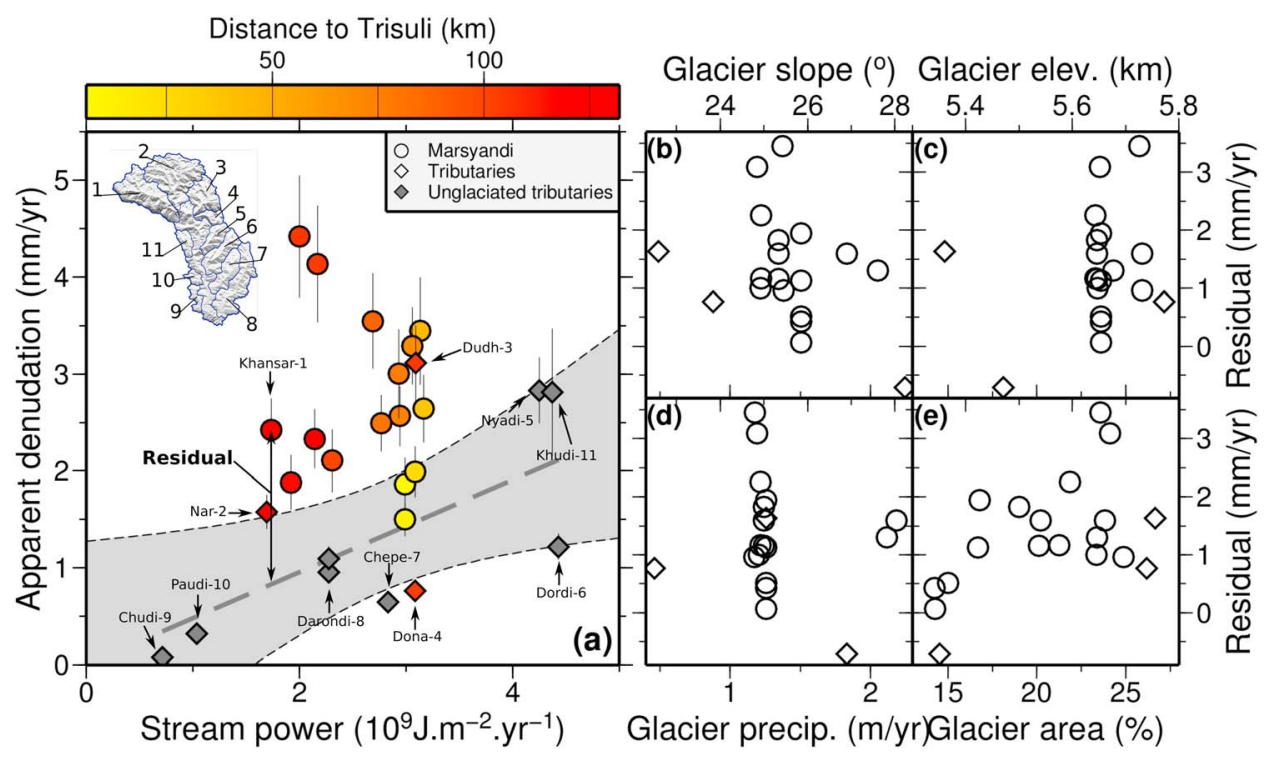

Figure 5. (a) Apparent denudation rates as a function of average specific stream power in the fluvial domain for basins corresponding to the samples presented in this study. For the purpose of this figure, apparent denudation rates are computed from the ${ }^{10} \mathrm{Be}$ concentration under the hypothesis that only the fluvial domain (fluvial network and hillslopes connected to it) contributes sediments, and that, as a consequence, no denudation occurs under the glaciers or on the hillslopes above them (see Figure $4 \mathrm{~d}$ for the delineation of the different domains). Similarly, the average specific fluvial stream power includes only the fluvial parts of the landscape. The thick dark gray dashed line is a linear regression $\left(R^{2}=0.85\right)$ forced through zero for the unglaciated catchments (dark diamonds for which the glaciated area is $<10 \%$ ), with $95 \%$ confidence envelope. The slope of the regression line is $4.810^{-13} \mathrm{~m}^{3} / \mathrm{J}$. The color code corresponds to the along-stream distance to the confluence with the Trisuli, and indicates the relative position of the samples inside the Marsyandi catchment and their distance from the headwaters. Numbers next to catchments names are keyed to the inset. In order to analyze the possible causes for the deviation from the trend defined by the unglaciated catchments, we plot the amplitude of this deviation as a function of different parameters that can be related to the erosive efficiency of the glaciers. (b) Average slope of the glaciers inside the basin, which can influence the ice flow velocity. (c) Mean glacier elevation, which can influence the mass balance. (d) Fraction of glaciated area in the catchment, which can be related to the total amount of glacial erosion occurring inside the catchment. (e) Mean annual precipitation over the glaciers inside the basin which can influence the mass balance.

geomorphological environment of those glaciers, such as average slope (Figure 5b) or annual precipitation (Figure 5d). A general increase of the residual with the fraction of glacial cover (Figure 5e) is clear, as would be expected if glacial erosion influences the CRN signal. We do not however observe any significant trend or correlation in Figures $5 \mathrm{~b}-5 \mathrm{~d}$, an absence which points toward complex dynamics and diverse spatial patterns of denudation. We suspect that the combination of sediments with almost no ${ }^{10} \mathrm{Be}$ from underneath the glaciers and sediments derived from the supraglacial hillslopes, with high production rates and variable denudation, contributes to generate this complex pattern.

[20] We note that the linear or non-linear nature of the dependency of erosion on landscape metrics such as stream power or steepness index is actively debated [Kirby and Whipple, 2001; Ouimet et al., 2009; DiBiase et al., 2010; Bookhagen and Strecker, 2012]. Our limited data set of unglaciated catchments suggests that a simple linear relationship provides an acceptable fit, but further discussion on its physical meaning would require additional sampling of such catchments. Stochastic inputs of low-dose sediments by mass wasting could be an alternative explanation for the apparent dilution in our data, as it is clearly impacting the ${ }^{10} \mathrm{Be}$ concentration in studies investigating small catchments [e.g., Norton et al., 2010]. However our typical catchment size is significantly above the $70-100 \mathrm{~km}^{2}$ value proposed by Niemi et al. [2005] and Yanites et al. [2009], such that we are quite confident that the contribution of processes such as landsliding is effectively averaged in our signal.

[21] For tributary junctions involving catchments of comparable size, such as the Khansar and the Nar, it is possible to assess the sediment mixing efficiency [Binnie et al., 2006]. The ratio of the apparent denudation rates (Figure 5) for these two catchments is $\sim 1.5$, whereas simple sediment mixing considerations based on the respective catchment areas and the ${ }^{10} \mathrm{Be}$ concentrations upstream and downstream of the junction [Binnie et al., 2006] predict a ratio of $\sim 1.1$. This difference might be interpreted as the manifestation of imperfect mixing across this confluence, but in our case this mismatch can also be related to the overestimation of the 
actual denudation in the Khansar catchment due to a larger, but unaccounted for, contribution of sediments produced by glaciers, with respect to the Nar. Farther downstream, when reaching the lowlands, the ${ }^{10} \mathrm{Be}$ concentration in the Marsyandi becomes less and less sensitive to contributions from tributaries due to the high volume of sediments that are already transiting along the main trunk.

\section{Quantitative Assessment of the Distribution and Intensity of Denudation}

\subsection{Outline of the Approach}

[22] In this section, we attempt to go beyond the simple qualitative considerations of the previous section and derive a physically based understanding of the evolution of the ${ }^{10} \mathrm{Be}$ concentration in the Marsyandi catchment and, in particular, the dilution associated with glacial erosion. We want to emphasize that the primary purpose of our simple mass-conservation budget goes beyond an effort to obtain estimates for the different parameters controlling catchmentscale denudation. Instead, our focus is to understand both the amount of the observed variability in our data set that can be explained by first-order representations of fluvial and glacial erosion processes, as well as the magnitude of the remaining unexplained signal.

[23] We consider that the total volumetric flux of quartz, $F_{t}$ (dimension $\left[L^{3} / T\right]$ ), transiting through a sampling point in the fluvial network is a mix of three distinct contributions: (1) $F_{f}$, the flux from denudation in the fluvial domain, i.e., the fluvial network and hillslopes connected to it, (2) $F_{g}$, the flux from erosion underneath the glaciers, and (3) $F_{g h}$, the flux from the hillslopes above the glaciers (supra-glacial hillslopes, $\mathrm{SGH}$ ):

$$
F_{t}=F_{f}+F_{g}+F_{g h}=\int_{f} f_{q z} \varepsilon d A+\int_{g} f_{q z} \varepsilon d A+\int_{g h} f_{q z} \varepsilon d A
$$

The parameter $f_{q z}$ is the concentration of the quartz fraction in the corresponding sediments, $A$ is area, and $\varepsilon$ is the denudation rate $([L / T])$ associated with a number of processes that will be subsequently specified. The subscripts $f, g$ and $g h$ refer to the fluvial, glacial and supra-glacial hillslopes domains, respectively. Note that, when constructing this sediment-flux budget, we are assuming that all three domains are producing material with similar grain size distributions, an assumption that will be discussed subsequently. The average concentration of ${ }^{10} \mathrm{Be}$, $\left[{ }^{10} B e\right]_{\text {avg }}([$ atoms $/ M])$, in any sediment collected along the network (which is what we measure in our samples) will be,

$$
\left[{ }^{10} \mathrm{Be}\right]_{\mathrm{avg}}=\frac{1}{F_{t}} \int_{f+g+g h} f_{q z} \varepsilon\left[{ }^{10} \mathrm{Be}\right] d A
$$

We distinguish between these three components because we assume that they have distinct properties in terms of erosion processes and accumulation of in-situ ${ }^{10} \mathrm{Be}$ (Figure $4 \mathrm{~d}$ ). In order to produce a formulation that is tractable, our mass balance has to rely on several simplifying assumptions for these three contributions. We assume that glaciers are effectively shielding the underlying bedrock from cosmic rays and the sediments directly produced by glacial processes (glacial domain, $F_{g}$ ) have a zero concentration of ${ }^{10} \mathrm{Be}$. Second, we assume that the ${ }^{10} \mathrm{Be}$ concentration in quartz for sediments delivered by the other parts of the landscape (fluvial and glacial hillslopes domains, $F_{f}$ and $F_{g} h$ ) is related to the local denudation rate with the following classical relationship [von Blanckenburg, 2005],

$$
\varepsilon=\frac{P \Lambda}{\left[{ }^{10} B e\right] \rho},
$$

where $P$ and $\Lambda$ are the scaled production rates ([atoms $/ M / T]$ ) and attenuation length $\left(\left[M / L^{2}\right]\right)$, respectively. The $P \Lambda$ term is the summation of the spallogenic (Figure $4 \mathrm{~b}$ ) and muonic contributions, and $\rho$ is the material density $\left(\left[M / L^{3}\right]\right)$. We also parameterize denudation acting on the fluvial part of the landscape (rivers and hillslopes contributing directly to them) by assuming that the pace of denudation of the threshold hillslopes [Gabet et al., 2004b] above the fluvial channels is controlled by river down-cutting and incision, such that spatially averaged denudation is considered to be directly proportional to some measure of river erosive power: in our case, specific stream power, $\Omega$ (Figure 4e),

$$
F_{f}=\int_{f} f_{q z} \varepsilon d A=\alpha \int_{f} f_{q z} \Omega d A
$$

The parameter $\alpha$ is the proportionality factor relating specific stream power to the denudation rate and is analogous to an erodibility constant [Howard et al., 1994; Sklar and Dietrich, 2001; Tucker and Whipple, 2002; Lavé and Avouac, 2001; Godard et al., 2010]. We assume that glacial erosion is constant throughout the glaciated parts of the Marsyandi catchment and that the supra-glacial hillslopes have their denudation rate set to that of the glacier below them [Heimsath and McGlynn, 2008; O'Farrell et al., 2009],

$$
F_{g+g h}=\int_{g+g h} f_{q z} \varepsilon d A=\varepsilon_{g} \int_{g+g h} f_{q z} d A
$$

Our goal is to solve for the parameters defining fluvial $(\alpha)$ and glacial $\left(\varepsilon_{g}\right)$ erosion inside the catchment.

[24] On the basis of the point-counting data of Brewer et al. [2006] and Garzanti et al. [2007], we consider that quartz abundance in the sediments derived from the denudation of the Tethyan Series, where carbonates dominate, is $1 / 5$ of that of the Lesser and Greater Himalayas (Figure 2).

\subsection{A Two-Parameter Simple Linear Model}

[25] As stated above, we assume that glacial erosion is constant across the Marsyandi catchment, i.e., all glaciers are eroding at the same rate independently of their position within the range. We combine equations (1), (2) and (3) along with the simplified formulations for denudation (equations (4) and (5)), and derive the following relation that relates the $\mathrm{CRN}$ concentration to the fluvial and glacial erosion rates,

$$
\alpha \int_{f} f_{q z} \Omega d A+\varepsilon_{g} \int_{g+g h} f_{q z} d A=\frac{1}{\left[{ }^{10} B e\right]_{\text {avg }}} \int_{f+g h} f_{q z} \frac{P \Lambda}{\rho} d A
$$

This equation can be rearranged as,

$$
\alpha \frac{\int_{f} f_{q z} \Omega d A}{\int_{g+g h} f_{q z} d A}+\varepsilon_{g}=\frac{1}{\left[{ }^{10} B e\right]_{\text {avg }} \cdot \int_{g+g h} f_{q z} d A} \int_{f+g h} f_{q z} \frac{P \Lambda}{\rho} d A .
$$




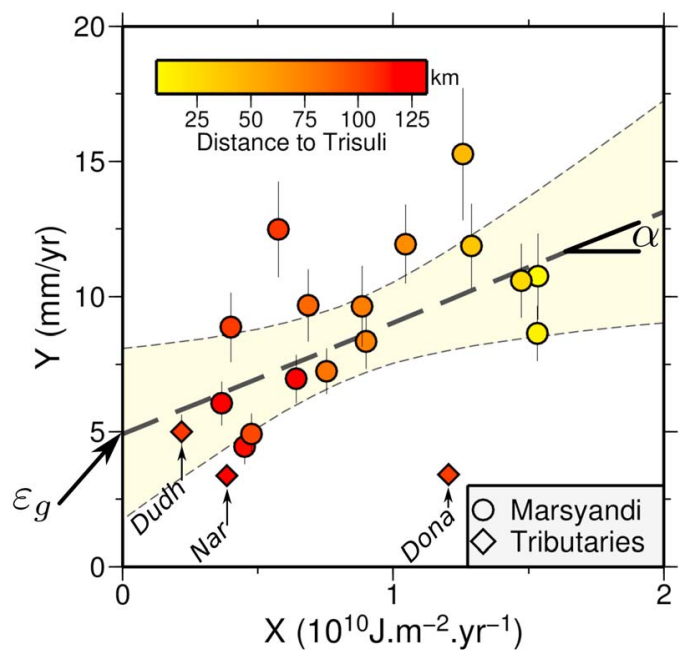

Figure 6. $X$ and $Y$ values (equation (8)) corresponding to our data points. The underlying assumption is that glacial erosion is constant over the whole Marsyandi catchment. Dashed line is a least-squares regression $\left(R^{2}=0.28\right)$ through this data set that allows us to constrain the erosion parameters used in the mass balance formulation: the erosion efficiency coefficient and the average apparent glacial erosion $\left(\alpha=4.1 \pm 3.210^{-13} \mathrm{~m}^{3} / \mathrm{J}\right.$ and $\varepsilon_{g}=4.9 \pm 3 \mathrm{~mm} / \mathrm{yr}$, respectively, $95 \%$ confidence intervals). Light yellow envelope is $95 \%$ confidence interval on the regression line. Symbol are colored according to the distance of the sampling point to the confluence of the Marsyandi with the Trisuli River, which provides a spatial reference frame for these results.

This equation is key in our analysis because it indicates that the parameters $\alpha$ and $\varepsilon_{g}$, i.e. the scaling factor (erodability) relating fluvial erosion to stream power (equation (4)) and the glacial erosion rate, respectively, are the slope and intercept of a linear relationship $\alpha X+\varepsilon_{g}=Y$, where

$$
X=\frac{\int_{f} f_{q z} \Omega d A}{\int_{g+g h} f_{q z} d A}, \text { and } Y=\frac{1}{\left[{ }^{10} B e\right]_{a v g} \cdot \int_{g+g h} f_{q z} d A} \int_{f+g h} f_{q z} \frac{P \Lambda}{\rho} d A
$$

The $X$ and $Y$ parameters are analogous to the basin-averaged specific stream power and apparent denudation, respectively, used in Figure 5, but are explicitly incorporating the contribution of glacial erosion. For each sampling point for which we have measured a value for the concentration of ${ }^{10} \mathrm{Be}$ $\left(\left[{ }^{10} B e\right]_{\text {avg }}\right)$, we can calculate $X$ and $Y$ using standard GIS techniques, and thus, by direct linear regression, we can derive estimates of the values of $\alpha$ and $\varepsilon_{g}$.

[26] When applied to our data set, the calculation of variables $X$ and $Y$ (Figure 6) shows significant scatter but also reveals an overall increase of $Y$ values with $X$. As explained above, under our working assumptions and simplifications, the intercept of the regression line on this data set is an estimation of the average value for the glacial erosion rate over the catchment. This estimate is $\sim 5 \mathrm{~mm} / \mathrm{yr}$ in the case of the Marsyandi (Figure 6). One reason for the large scatter is most likely the failure to take into account the spatial variability of geomorphic processes and, in particular, of glacial erosion across the climatic gradients observed within the Marsyandi catchment (Figure 4c). The scatter around the regression line when using this simple formulation suggests the utility of expanding this formalism in order to integrate intra-catchment variations in the intensity of glacial erosion.

\subsection{Spatial Variability in Glacial Erosion}

[27] The Marsyandi catchment encompasses large glaciated areas with striking contrasts in climatic and geomorphic environments [Bookhagen and Burbank, 2006; Gabet et al., 2004b]. The mass balance of these glaciers and, specifically, the ice flux is expected to vary significantly between the monsoon-drenched glacial systems of the south flank and drier areas located inside the rainshadow, such as glaciers of the Nar tributary [Harper and Humphrey, 2003; PrattSitaula, 2005; Bookhagen and Burbank, 2006]. Given the apparent correlation between ice flux and glacial erosion rates [e.g., Humphrey et al., 1986; Hallet, 1996], the assumption that glacial erosion intensity is constant over the whole catchment, as postulated in the previous section, is difficult to support [Scherler et al., 2011a]. In this section, we further develop the mass-conservation formalism by allowing glacial erosion to vary in space. Such spatial variability is introduced in our approach by defining an average glacial erosion rate at the sub-catchment scale, rather than for the whole catchment, i.e., we consider glacial erosion to be constant within each of the major tributary basins to the Marsyandi (Figure 4a).

[28] We decompose the glacial and glacial-hillslope domains of the previous section into a number of subdomains corresponding to the $m$ major tributaries of the Marsyandi (Figure 4a), such that the total flux of quartz out of these domains as seen in the i-th sample is:

$$
F_{g+g h, i}=\sum_{j}^{m} \varepsilon_{g, j} \int_{(g+g h), i, j} f_{q z} d A=\sum_{j}^{m} \varepsilon_{g, j} A_{i j}^{\prime}
$$

where $A_{i j}^{\prime}$ is the area of the intersection between the catchments of i-th sample and the j-th Marsyandi tributary, weighted by the quartz abundance in the bedrock.

[29] This expression for the glacial and supra-glacial hillslopes flux can be used in equation (6), and, for $m$ major tributaries and $n$ samples, this formulation can be cast in matrix form as,

$$
\begin{aligned}
& \left(\begin{array}{cccccc}
A_{11}^{\prime} & \cdots & A_{1 j}^{\prime} & \cdots & A_{1 m}^{\prime} & \int_{f, 1} f_{q z} \Omega d A \\
\vdots & \ddots & \vdots & \ddots & \vdots & \vdots \\
A_{i 1}^{\prime} & \cdots & A_{i j}^{\prime} & \cdots & A_{i m}^{\prime} & \int_{f, i} f_{q z} \Omega d A \\
\vdots & \ddots & \vdots & \ddots & \vdots & \vdots \\
A_{n 1}^{\prime} & \cdots & A_{n j}^{\prime} & \cdots & A_{n m}^{\prime} & \int_{f, n} f_{q z} \Omega d A
\end{array}\right)\left(\begin{array}{c}
\varepsilon_{g, 1} \\
\vdots \\
\varepsilon_{g, j} \\
\vdots \\
\varepsilon_{g, m} \\
\alpha
\end{array}\right) \\
& =\left(\begin{array}{c}
\frac{1}{\left[{ }^{10} B e\right]_{1}} \int_{f, 1} f_{q z} \frac{P . \Lambda}{\rho} d A \\
\vdots \\
\frac{1}{\left[{ }^{10} B e\right]_{i}} \int_{f, i} f_{q z} \frac{P . \Lambda}{\rho} d A \\
\vdots \\
\frac{1}{\left[{ }^{10} B e\right]_{n}} \int_{f, n} f_{q z} \frac{P . \Lambda}{\rho} d A
\end{array}\right),
\end{aligned}
$$




\section{Comparison of glacial erosion rates}

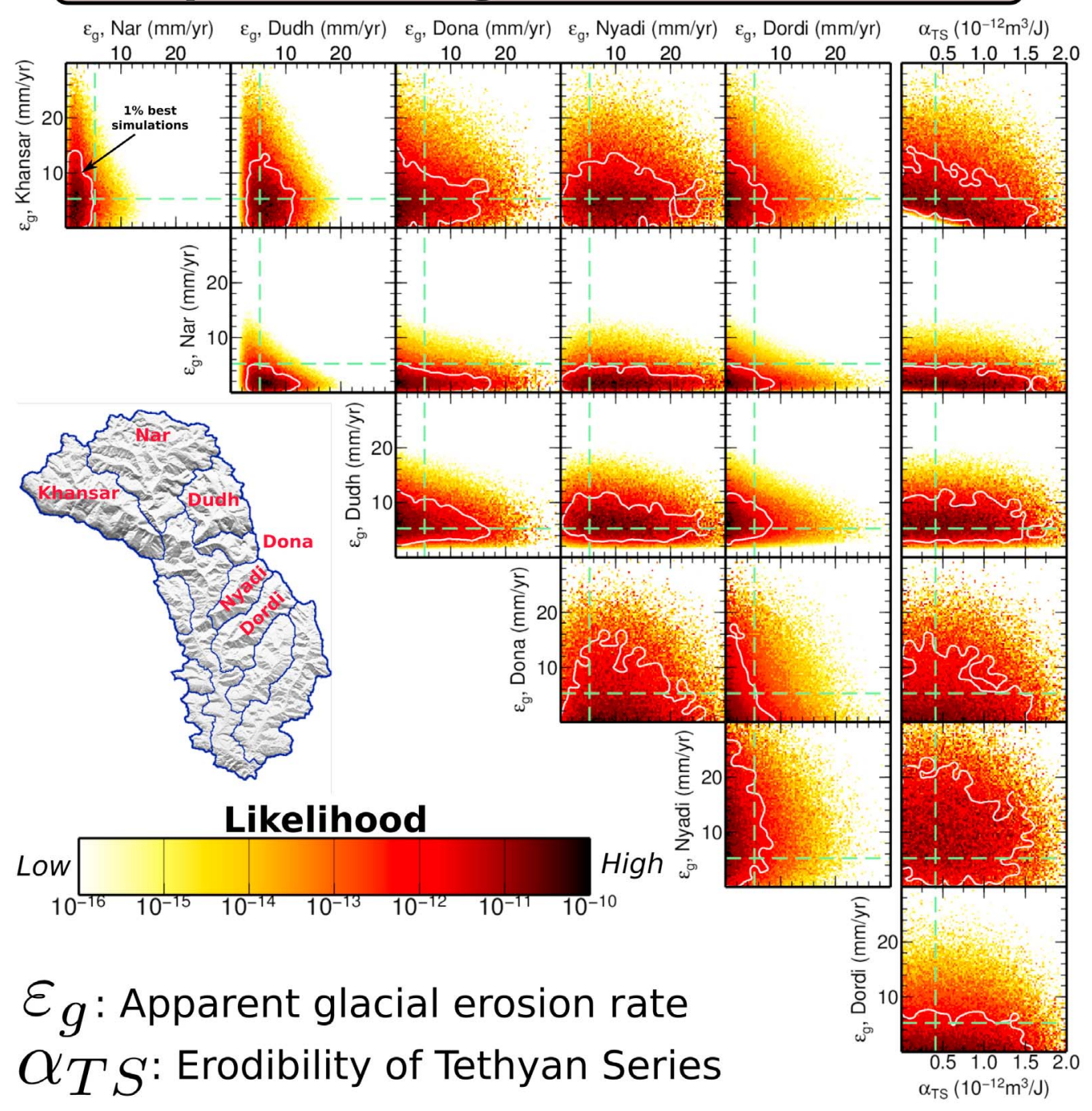

Figure 7. Results from the systematic exploration of parameter space for each parameter couple (glacial erosion rates inside the glaciated catchments $\varepsilon_{g}$ and erodibility of the Tethyan Series $\alpha_{T S}$ ), with color scale corresponding to likelihood (equation (11)). Thin dashed green lines indicate the solutions obtained in Figure 6 . Thin white contours delineate the best $1 \%$ in all the simulations performed.

At this point, we can further refine the analysis by introducing distinct erodibility coefficients $(\alpha)$ for each of the three litho-tectonic packages of the Marsyandi catchment: the Lesser Himalayas, Greater Himalayas and Tethyan Series domains (Figure 2). Previous studies have demonstrated that the properties of the Lesser and Greater Himalaya formations with respect to denudation do not appear to be significantly different [Lavé and Avouac, 2001; Attal and Lavé, 2006; Godard et al., 2006; Craddock et al., 2007] and we already have an estimation of the value of this parameter from the unglaciated catchments of Figure 5 (gray diamonds). Thus, in the following analysis, we will only consider the erodibility of the Tethyan Series $\left(\alpha_{T S}\right)$ as a free parameter and set that of the other units to the value we have previously determined.

[30] On the basis of the linear system of equations defined by equation (10), we can predict an expected ${ }^{10} \mathrm{Be}$ concentration at $n$ sampling points for any combination of values of $m$ glacial erosion rates $\left(\varepsilon_{g}\right)$ and the erosion efficiency parameter $\left(\alpha_{T S}\right)$, and we can calculate a likelihood $L$ [Herman et al., 2010],

$$
L=\exp \left(\frac{-1}{n} \sum_{i}^{n} \frac{\left[{ }^{10} B e\right]_{o b s e r v e d, i}-\left[{ }^{10} B e\right]_{\text {predicted }, i}}{\sigma_{i}}\right) .
$$

This likelihood criterion is maximized to extract the bestfitting values; this maximization is attained by randomly exploring the parameter space (Figure 7).

\subsection{Results}

[31] Based on these analyses (equations (10) and (11)), we observe that the maximum likelihood apparent glacial erosion rates for the three northernmost catchments (Khansar, Nar and Dudh) display relatively restricted distributions (Figure 7), whereas for other parameters, such as the 


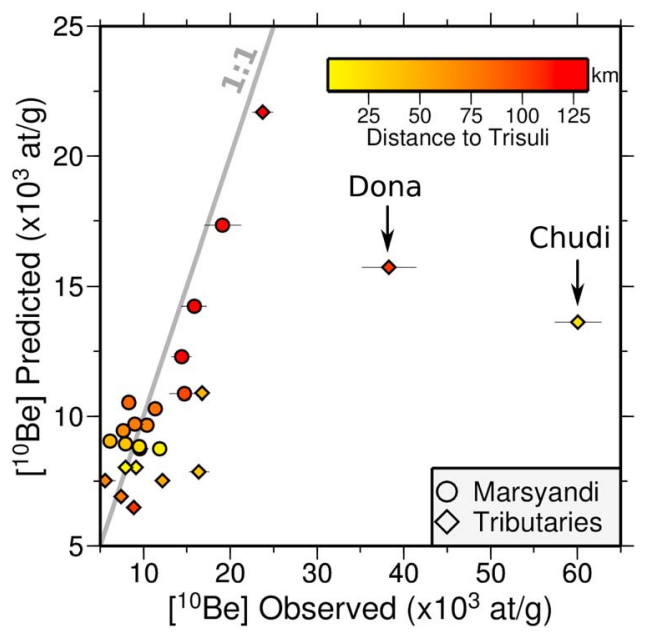

Figure 8. Comparison between the observed and predicted ${ }^{10} \mathrm{Be}$ concentrations at our sampling points along the Marsyandi river and its main tributaries. Predicted concentrations plotted here are calculated by taking the mean value of the predicted concentrations from the $1 \%$ best fitting sets of parameters (Figure 7).

erodibility constant of the Tethyan Series $\left(\alpha_{T S}\right.$ : Figure 7 (right)) or the apparent glacial erosion rates over the catchments farther downstream (Dona, Nyadi and Dordi), the values appear significantly more dispersed. These latter three downstream catchments join the Marsyandi in its middle reach, at a point where the fluvial sediment load is high and the contributions from individual catchments are likely to be strongly diluted: an unavoidable condition that will limit their impact on the ${ }^{10} \mathrm{Be}$ content in the main trunk and, hence, on the obtained solution. As a consequence, the range of acceptable values for their apparent glacial erosion rates will be broader and the final resolution weaker. In terms of estimating the erodibility of the Tethyan Series, it should be noted that these formations have a low quartz content [Brewer et al., 2006], which limits the impact of variations in their rate of denudation on the total volume of Tethyanderived quartz that transits through the Marsyandi. This low quartz abundance is a primary cause for the poor resolution on the $\alpha_{T S}$ parameter. For the three upper catchments, we note that the predicted apparent glacial erosion ranges in the Dudh and Khansar catchments are significantly higher (4-10 and $<10 \mathrm{~mm} / \mathrm{yr}$, respectively) than what is observed in the more northerly Nar catchment $(<2 \mathrm{~mm} / \mathrm{yr})$ that lies within the rainshadow.

[32] We also note the existence of a negative correlation between the erodibility of the Tethyan series and the apparent glacial erosion rate in the Khansar catchment, which drains almost exclusively Tethyan sediments. This relation suggests that the concentration in ${ }^{10} \mathrm{Be}$ of the sediments coming out of this catchment is highly sensitive to changes in the erodibility of these formations such that a decrease in $\alpha_{T S}$ leads to increased concentrations that can be compensated for by a dilution from increased glacial erosion.

[33] We can use the estimates of the denudation parameters derived from our optimization (Figure 7) to calculate predicted values of the ${ }^{10} \mathrm{Be}$ concentration at our sampling points along the Marsyandi and its main tributaries (Figure 8). We note that for several tributaries the predicted concentration is significantly lower than what is actually observed, as for example, in the Chudi and Dona. This variability cannot be explained by our simple mixing model and points to more complex processes, such as the contribution of sediments derived from Quaternary terraces or moraines.

[34] Due to several significant simplifications that are discussed below, however, we emphasize that these results are only semi-quantitative estimates for the magnitude of glacial erosion. For example, we propose that, based on our inversion results (Figure 7), the average apparent glacial erosion rate within the Nar catchment is $<2 \mathrm{~mm} / \mathrm{yr}$, whereas it is likely to be higher in the adjacent Dudh catchment (4$10 \mathrm{~mm} / \mathrm{yr}$ ). Such results have the merits of providing an order-of-magnitude estimate and a spatial distribution for these processes that can be discussed in terms of variations of the geomorphological environment of these catchments (Figures 4c-4f). Any attempts to refine the glacial erosion rates to a resolution of $1 \mathrm{~mm} / \mathrm{yr}$ or less is clearly inappropriate with these data. We emphasize that glacial-flow velocities can vary highly at small spatial scales and can potentially result in different erosion rates [Scherler et al., 2011b].

\section{Discussion}

\subsection{Simplifying Assumptions in the Inversion Approach}

[35] The simple mass balance model that we employ in this article relies on several assumptions and simplifications that require critical examination. Whereas our primary aim is to provide a comprehensive framework for the main trends and patterns in our data, inevitably, significant variance exist that cannot be explained by our simple approach and points to the contribution of additional factors and processes. We have partitioned the Marsyandi area into three distinct processoriented domains (fluvial, glacial, and supra-glacial hillslopes) (Figure 4d). This distinction has a functional significance, but it provides a highly simplified view of denudation acting within the catchment. The scaling of denudation with specific stream power or a similar metric in the so-called fluvial domain is common practice and has been broadly validated in several previous studies [Lavé and Avouac, 2001; Kirby et al., 2003; Safran et al., 2005; Craddock et al., 2007; Godard et al., 2010; Siame et al., 2011; Abbühl et al., 2011; Bookhagen and Strecker, 2012]. On the other hand, denudation processes acting under glaciers and connected hillslopes are far more difficult to parameterize, which is why we limit ourselves to a far-field perspective by only defining an average denudation rate acting over these domains.

[36] Superficial Quaternary deposits that occur within the Marsyandi catchment [Lavé and Avouac, 2001; Weidinger, 2006; Attal and Lavé, 2006; Pratt-Sitaula et al., 2007] could add a relatively highly ${ }^{10} \mathrm{Be}$ dosed CRN contribution to the sediments transiting into the fluvial network. Possible candidates are, for example, the Late Quaternary moraines present in the Khansar, Dudh and Dona sub-catchments [PrattSitaula, 2005; Zech et al., 2009], landslides such as those present in the upper Marsyandi valley [Weidinger, 2006], 
alluvial and debris flow formations that are well exposed in terraces along the Marsyandi valley [Pratt-Sitaula et al., 2004], or extensive supra-glacial debris. All these contributions will cause deviations from the simple mass balance proposed here, which is assuming steady state in terms of sediment flux and no temporary storage of sediments inside the catchment. They may explain some data outliers such as the high concentration in ${ }^{10} \mathrm{Be}$ of some Lesser Himalayan catchments, such as the Paudi or Chudi (Figure 3). If significant contributions have come from such more highly dosed sediments, the apparent glacial erosion rates derived here should be considered minimum values.

[37] Another important problem associated with our proposed approach is the assumption that the sediments produced by the different processes acting inside the catchment share a common grain-size distribution. This assumption should be considered with caution when dealing with contributions from both glaciated and unglaciated areas. In particular, one could argue that supra-glacial hillslopes deliver coarser sediments than sub-glacial processes and that their contribution would be underrepresented in the $250-1000 \mu \mathrm{m}$ sediment size that we analyze here. Such an omission would result in an underestimation of the contribution of these hillslopes to the sediment flux. Under the assumption that glacial hillslope denudation rates are set equal to those imposed by the erosion directly under glaciers, the missing hillslope contribution will induce glacial erosion rates to be underestimated.

[38] As with every study using CRN in river sands to infer denudation at catchment scales, one needs to be sure that the different processes acting in the landscape are effectively integrated in space and time to deliver a reliable estimate of denudation. The catchments that we analyze are large enough to perform this integration of the stochastic hillslope processes such as landsliding [Yanites et al., 2009]. Similarly, we also note that some recently deglaciated surfaces are likely to be out of equilibrium with the denudation pace imposed by the fluvial network, but we are assuming that this only affects small portions of the total landscape that are not going to significantly affect our sediment budget.

[39] As stated previously, we also find that catchments that have low glacial coverage or join the main trunk significantly downstream of the headwaters of the Marsyandi, such as the Dona, Nyadi or Dordi (Figure 4a), have relatively poorly defined apparent glacial erosion rates (Figure 7) when compared to other catchments. Because these catchments either lie in the lower reaches of the Marsyandi watershed or are relatively small, they ultimately have a limited impact on the magnitude and nature of the sediment flux at the point where they join the Marsyandi [Gabet et al., 2008]. Their modest impact limits our ability to decipher their erosion pattern based on the inversion of the ${ }^{10} \mathrm{Be}$ signal. Because such progressive downstream dilution and loss of information is an important constraint on the applicability of this approach, the topological and geomorphological properties of any candidate catchment deserve careful evaluation.

\subsection{Sensitivity Analysis}

[40] In order to assess the potential implications of the limitations mentioned in the previous section, we perform a series of tests and sensitivity analyses for the multiparameter inversion. We first investigate the influence of random variations in our data set on the structure of the solutions that we obtained. For that purpose, we randomly resample every data point using a normal distribution whose parameters are the measured concentration as mean and the analytical $1 \sigma$ uncertainty as standard deviation. Then we run the inversion using this new synthetic data set. After five repetitions of this randomization and inversion (Figure 9a), the resultant solutions in each case are very similar to the initial results from Figure 7. This observation suggests that our results are robust and are largely unaffected by the uncertainties in the observations.

[41] We also investigate the influence of the quartz content in the Tethyan Series by decreasing it from $20 \%$ in the initial inversion (Figure 7) down to 10\% (Figure 9b). The resultant ranges of parameters are unaffected by this change, which is consistent with the moderate influence of the sediment flux out of the Tethyan Series, as we suggested above.

[42] A possible issue with sediment derived from the supra-glacial hillslopes ( $\mathrm{SGH}$ ) is that they can be transported by glaciers as a debris cover where they can accumulate a significant amount of ${ }^{10} \mathrm{Be}$ during this transport. Glacial surface velocities derived from image-cross correlation suggests that this debris would have a residence time of 50 to 150 years on the steep Himalayan glaciers, depending on glacial size and location where debris entered the glacial system [Scherler et al., 2011a]. This duration also reflects the glacial response time. Such an effect is difficult to incorporate explicitly into our formalism, but in order to study its possible magnitude, we double or triple the CRN production rate on the supra-glacial hillslopes to account for an additional dosing of the corresponding sediments during their transport on a glacier surface. We note that this exposition may occur mostly below the ELA, as the debris are usually covered by snow above the ELA. As in the previous series of tests, we observe no significant modification to the overall pattern for most of the parameters (Figure 9b), except in the Dudh catchment where the apparent glacial erosion rate accelerates in order to increase the dilution by subglacial sediment and to compensate for the additional amount of ${ }^{10} \mathrm{Be}$ from supra-glacial hillslopes sediments.

[43] As mentioned in the previous section, a significant limitation of our approach is that different parts of the landscape produce sediments with different size distributions, which can bias the mass conservation budget that we try to set up. We can, for example, postulate that the supraglacial hillslopes are delivering relatively coarser sediments that will be underrepresented in the analyzed fraction with respect to the actual contribution of these hillslopes when considering the total eroded material volume. To assess the influence of such bias, we modify our formalism by cutting the flux of sediments from the supra-glacial hillslopes in half or completely in our budget. We observe that most parameters are unaffected in their ranges by this reduction (Figure 9c), with the exception of the apparent glacial erosion rate for the Dudh catchment, which displays a significant increase to the $10-20 \mathrm{~mm} / \mathrm{yr}$ range when the sediment flux from the supra-glacial hillslopes is completely shut down. Of all the studied catchments, the Dudh catchment has the highest areal proportion of supra-glacial hillslopes (Figure 4d): a factor that is likely to be the main reason for such sensitivity. Similar questions can be asked about the 


\section{Sensitivity analysis}

(a) Resampling of the dataset

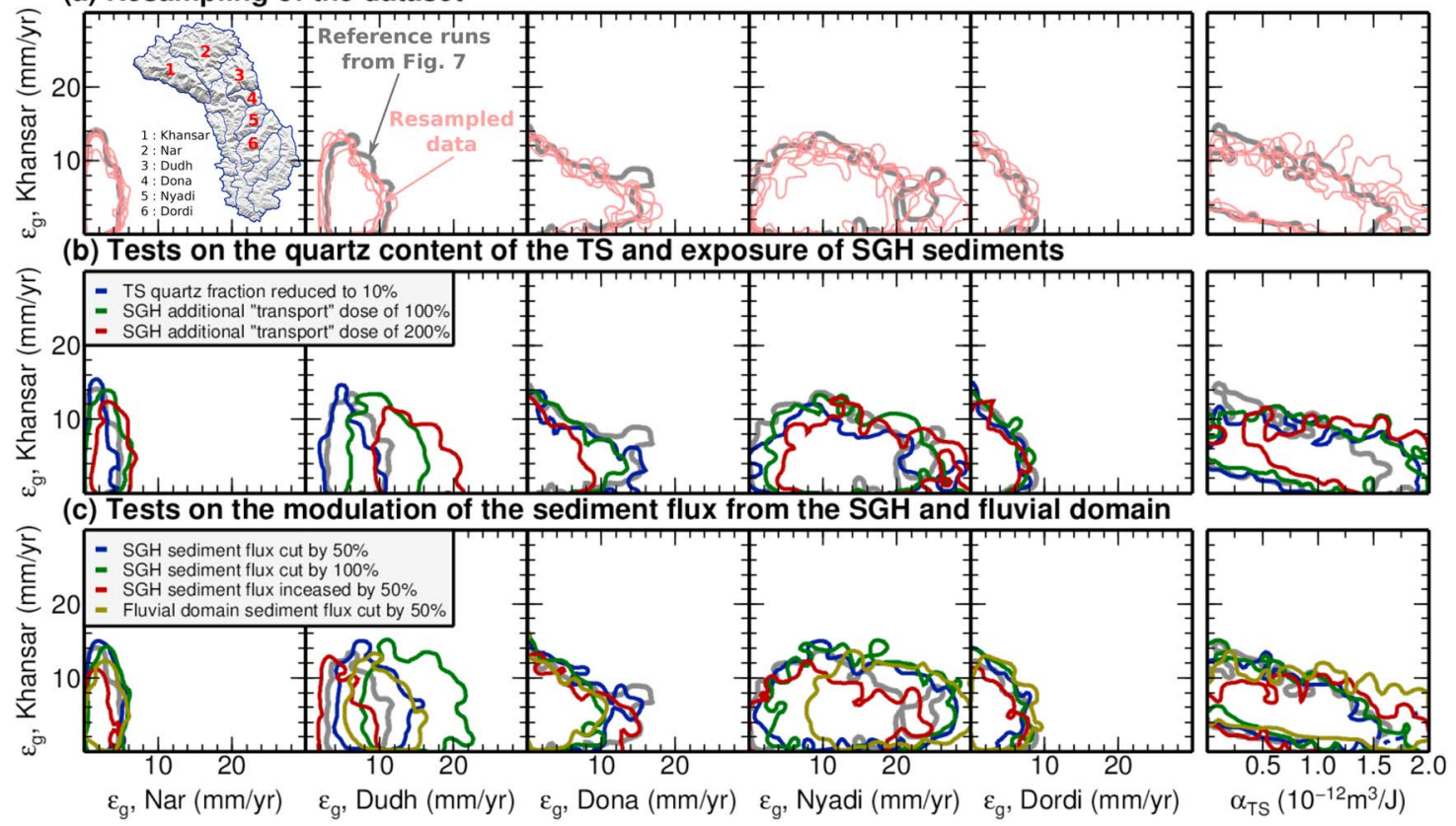

Figure 9. Sensitivity analysis for the inversion presented on Figure 7. For reference, thick dark gray contours delineate the best $1 \%$ of the simulations presented on Figure 7. (a) Light red contours are results for sensitivity tests where the data set is randomly resampled assuming a normal distribution for each sample with mean and standard deviation based on measured ${ }^{10} \mathrm{Be}$ concentration and the $1 \sigma$ uncertainty. Five different tests are plotted each with its own resampling of the data set. (b) Blue contours: the quartz abundance in the Tethyan series is assumed to be $10 \%$ instead of $20 \%$ as in Figure 7 . Green contours: The ${ }^{10} \mathrm{Be}$ production on the supra-glacial hillslopes ( $\mathrm{SGH}$ ) is multiplied by a factor 2 . This doubling is intended to test the influence of additional ${ }^{10} \mathrm{Be}$ accumulation during the transport of these sediments as supraglacial debris cover. Red contours: same as previous test, but production on the supra-glacial hillslopes is multiplied by a factor 3. (c) Blue contours: only $50 \%$ of the sediments produced on the supra-glacial hillslopes are effectively incorporated in the sediment budget. This reduction is done to test the sensitivity of the inversion to differences in the size distribution of the sediments produced by different parts of the landscape. Green contours: same as previous test but sediment flux from the supra-glacial hillslopes completely removed from the budget. Red contours: erosion on the supra-glacial hillslopes increased by $50 \%$. Yellow contours: sediment flux from the fluvial domain cut by $50 \%$.

size distribution of the contribution from the hillslopes of the fluvial parts of the landscape which are also likely to deliver coarser sediments than the glaciers. We test the implications of a $50 \%$ decrease in the flux from the sediment from the fluvial domain (Figure 9c). It should be noted that such modulation consists in removing a part of the volume of sediments in our budget, but does not change the ${ }^{10} \mathrm{Be}$ concentration of the sediments from the fluvial landscape. For that reason, this modification has no impact on the misfit between observed and predicted concentrations (equation (11)) for unglaciated catchments and only limited influence for large catchments with relatively low glacial cover, such as the lower reach of the Marsyandi. As for the previous tests on the flux of from supra-glacial hillslopes, only the Dudh displays a significant increase in its glacial erosion rate. Other changes in the parameters are within the range the variability of the solution associated with the uncertainties on the data as illustrated by Figure 9a.

[44] Another important assumption of our analysis is that we consider the erosion rates under the glacier and on the supra-glacial hillslopes to be equal. It can be proposed that, under changing climate conditions, the retreat of glaciers induces a debutressing and enhanced denudation on the supra-glacial hillslopes. To test the impact of such scenario we increase the denudation of the supra-glacial hillslopes by $50 \%$ with respect to the glacial erosion rate (Figure 9c). We observe a slight decrease of the range of values for some of the apparent glacial erosion rates, which balance the increase in the sediment flux from the supra-glacial hillslopes.

\subsection{Comparison With Other Estimates for Denudation in the Himalayas of Central Nepal}

[45] We interpret our data as reflecting a significant contribution of glacially derived sediment that lowers the ${ }^{10} \mathrm{Be}$ signal downstream and renders impracticable the usual derivation of reliable basin-wide denudation rates from CRN concentrations in river sediments (Figure 5).

[46] The order of magnitude of our apparent glacial erosion rates in the Greater Himalaya is higher than the indirect estimates of Heimsath and McGlynn [2008] on the Milarepa 
Spatial variations in erosion

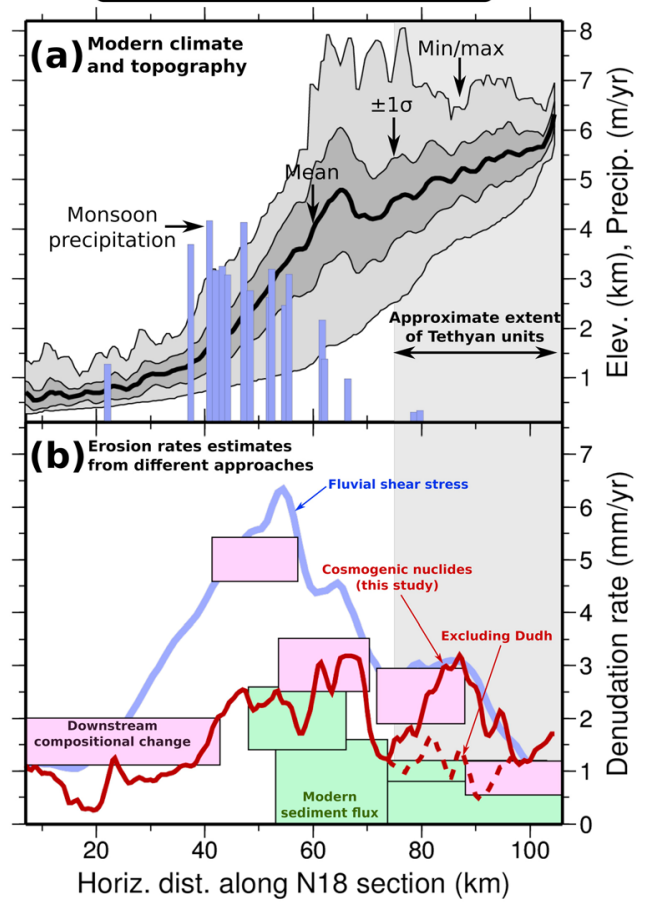

Figure 10. (a) Topography and precipitation [Burbank et al., 2003] projected along a N18 trending cross section perpendicular to the strike of the range. The different envelopes for topography correspond to the extrema and $\pm 1 \sigma$ ranges. (b) Erosion estimates in the Marsyandi catchment. Red line is the spatially averaged denudation along the previous cross section including the contributions of the fluvial and glacial domains, based on our analysis of detrital CRN concentrations. Dashed red line is the average denudation when the contribution of rapid glacial erosion in the Dudh catchment is excluded. Denudation in the fluvial domain is derived from calculated specific stream power (Figure 4e) and the erosion efficiency parameter $\alpha$ that was determined for the Lesser and Greater Himalayas (Figure 5) and the Tethyan series (Figure 7). Background data are the average fluvial incision profile across the range derived from shear stress calculation [Lavé and Avouac, 2001], erosion estimates from downstream compositional changes of river sediments [Garzanti et al., 2007] and modern sediment fluxes [Gabet et al., 2008].

glacier on the northern flank of the Annapurnas (0.46 \pm $0.16 \mathrm{~mm} / \mathrm{y}$ of vertical lowering of the headwalls). This previous study examined a single small glaciated catchment, whereas our study investigates glacial erosion over the whole Marsyandi in a manner that is likely to smooth any localized short-wavelength variability in the intensity of glacial processes. As noted by Heimsath and McGlynn [2008], the relatively low glacial rates documented by them are an order of magnitude lower than rates of fluvial incision documented in some adjacent locations along the Marsyandi River [Pratt et al., 2002; Pratt-Sitaula et al., 2004], a contrast that led them to conclude that, at least in some parts of the catchment, glaciers are not able to keep pace with fluvial downcutting. This contrast can also be related to the difference in operational time-scales for glacial and fluvial erosion processes
[Seong et al., 2009; Ward and Anderson, 2011]. This apparent inequality contrasts with our study, in which calculated ranges for apparent glacial erosion rates are approximately the same order of magnitude as denudation in the fluvially controlled areas. We also note that the order of magnitude of our estimates for glacial erosion are similar to what has been estimated in some other alpine glacial settings in active orogens [Hallet et al., 1996; Koppes and Montgomery, 2009].

[47] For the three northernmost catchments, we also observe that glacial erosion in the Nar, which is the driest of all Marsyandi sub-catchments (Figure 4c) is lower than in the adjacent Khansar and Dudh, which receive significantly more monsoon precipitation. This difference between the glacial erosion rates over these catchments supports the contention that climatic control on the mass balance and velocity of the glaciers is reflected in their erosional activity.

[48] Gabet et al. [2008] investigated basin-wide denudation rates for the upper Marsyandi catchment based on gauging of stream sediments, yielding estimates consistent with our findings in both magnitude and spatial distribution (Figure 10b) when we exclude the high glacial erosion rates of the Dudh catchment (Figure 4d). We note that our estimates for glacial erosion are slightly higher than Gabet et al.'s [2008], but that they are also more spatially restricted because they apply only to the currently glaciated area; these regions never exceed $25 \%$ for any sub-catchment of the Marsyandi. Further explanations for apparent discrepancies in rates could derive from the differences in the integration timescale of the two different approaches (decadal versus hundreds to thousands of years) [Kirchner et al., 2001]. We also acknowledge unquantified biases associated, in particular, with the possible under-representation of infrequent large-magnitude denudation and transport events in the sediment gauging record, which in the case of the study of Gabet et al. [2008] is on average 3 years.

[49] Based on the analysis of river profiles and mineralogical spectra of sediments, Lavé and Avouac [2001], Brewer et al. [2006] and Garzanti et al. [2007] have also provided constraints concerning the pattern and intensity of denudation in the Marsyandi area. The spatial distribution that they deduce shows a similar partitioning of low denudation in the slowly uplifting, but wetter lower part and dry, upper part of the catchment. In between, faster denudation prevails in the wet, actively uplifting topographic front of the Himalayas (Figure 10b). The magnitude of denudation that we document is consistent with the lower bound of these studies, and it appears that the intensity we propose for denudation is in between their estimates and the results of Gabet et al. [2008]. Again, we stress that these studies and ours relied on different methods that have their unique time-frame of integration, which may lead to the observed spread in the absolute rates, despite similar spatial patterns.

\section{Conclusion}

[50] Although quantification of rates of glacial erosion is integral to understanding processes and rates of landscape evolution in glaciated mountains, successful quantification is still difficult. Detrital cosmogenic nuclide concentrations offer the potential to delineate millennial glacial erosion rates, in such settings. 
[51] Along the Marsyandi River and its main tributaries in central Nepal, we have documented the evolution of the detrital ${ }^{10} \mathrm{Be}$ signal; a signal which reflects both the spatial variability of denudation in this catchment and dilution attributable to glacial erosion. For most sites, such mixed contributions make the direct derivation of basin-averaged denudation rates difficult and indicate the need to explore alternative approaches to analyze comprehensively data of this nature. We use a linear mixing model based on the conservation of ${ }^{10} \mathrm{Be}$ across the catchment to deconvolve the observed signal into contributions from different geomorphic realms and to put constraints on the magnitude and spatial distribution of the several denudational processes acting within the catchment. Of particular interest are the estimates for glacial erosion, averaging about $5 \mathrm{~mm} / \mathrm{yr}$ in the High Himalaya and Tethyan realm: areas for which previous estimates were sparse and poorly constrained.

[52] Further testing of the methodology described here is clearly necessary. Systematic sampling and analysis in regions with homogeneous rock types and precipitation, but encompassing catchments with a diversity of modern glacial cover, supra-glacial debris, sliding velocities, and supraglacial hillslopes may serve to advance efforts to use cosmogenic concentrations to derive reliable erosion rates in a particularly unpromising environment: the subglacial realm where cosmogenic production is close to zero.

[53] Acknowledgments. This research was funded by a Marie Curie Fellowship (Geocycl-219662) to VG and by NSF (EAR 0819874) and NASA (NNX08AG05G) grants to DWB and BB. Sample collection in 1997 was supported by NSF (EAR 9627865). Logistical support for field work in Nepal was provided by Bhim Chand from Earth's Paradise Treks, Travels \& Geologistics, Kathmandu. Discussions with Beth Pratt-Sitaula provided essential perspectives during the initial stage of the project. We thank Becky Streit for helping with the field work. SPOT satellite scenes used in this project were acquired through the ISIS (CNES) program. Numerous constructive comments by six reviewers and two Associate Editors helped us to improve the manuscript.

\section{References}

Abbühl, L., K. Norton, J. Jansen, F. Schlunegger, A. Aldahan, and G. Possnert (2011), Erosion rates and mechanisms of knickzone retreat inferred from ${ }^{10} \mathrm{Be}$ measured across strong climate gradients on the northern and central Andes Western Escarpment, Earth Surf. Processes Landforms, 36(11), 1464-1473.

Andermann, C., S. Bonnet, and R. Gloaguen (2011), Evaluation of precipitation data sets along the himalayan front, Geochem. Geophys. Geosyst., 12, Q07023, doi:10.1029/2011GC003513.

Anderson, R. S., B. Hallet, J. Walder, and B. F. Aubry (1982), Observations in a cavity beneath Grinnell Glacier, Earth Surface Processes and Landforms, 7(1), 63-70, doi:10.1002/esp.3290070108.

Anderson, R. S., P. Molnar, and M. A. Kessler (2006), Features of glacial valley profiles simply explained, J. Geophys. Res., 111, F01004, doi:10.1029/2005JF000344.

Armstrong, R. B., S. J. S. Raup, R. Khalsa, J. Barry, C. Kargel, Helm, and H. Kieffer (2005), GLIMS glacier database, http://nsidc.org/data/nsidc0272.html, Natl. Snow and Ice Data Cent., Boulder, Colo.

Attal, M., and J. Lavé (2006), Changes of bedload characteristics along the Marsyandi River (central Nepal): Implications for understanding hillslope sediment supply, sediment load evolution along fluvial networks and denudation in active orogenic belts, Geol. Soc. Am. Spec. Pap., 398, $143-171$.

Avouac, J. P. (2003), Mountain building, erosion, and the seismic cycle in the Nepal Himalaya, Adv. Geophys., 46, 1-80.

Avouac, J. P., and E. B. Burov (1996), Erosion as a driving mechanism of intracontinental mountain growth, J. Geophys. Res., 101(B8), 17,74717,770, doi:10.1029/96JB01344.

Belmont, P., F. J. Pazzaglia, and J. C. Gosse (2007), Cosmogenic ${ }^{10} \mathrm{Be}$ as a tracer for hillslope and channel sediment dynamics in the clearwater river, western Washington state, Earth Planet. Sci. Lett., 264(1), 123-135.
Berger, A. L., et al. (2008), Quaternary tectonic response to intensified glacial erosion in an orogenic wedge, Nat. Geosci., 1(11), 793-799, doi:10.1038/ngeo334.

Bierman, P., and E. J. Steig (1996), Estimating rates of denudation using cosmogenic isotope abundances in sediment, Earth Surf. Processes Landforms, 21(2), 125-139.

Binnie, S. A., W. M. Phillips, M. A. Summerfield, and L. Keith Fifield (2006), Sediment mixing and basin-wide cosmogenic nuclide analysis in rapidly eroding mountainous environments, Quat. Geochronology, 1(1), 4-14.

Blythe, A., D. Burbank, A. Carter, K. Schmidt, and J. Putkonen (2007), PlioQuaternary exhumation history of the central Nepalese Himalaya: 1. Apatite and zircon fission track and apatite [U-Th]/He analyses, Tectonics, 26, TC3002, doi:10.1029/2006TC001990.

Bollinger, L., J. P. Avouac, O. Beyssac, E. J. Catlos, T. M. Harrison, M. Grove, B. Goffé, and S. Sapkota (2004), Thermal structure and exhumation history of the Lesser Himalaya in central Nepal, Tectonics, 23, TC5015, doi:10.1029/2003TC001564.

Bookhagen, B. (2010), Appearance of extreme monsoonal rainfall events and their impact on erosion in the Himalaya, Geomatics Nat. Hazards Risk, 1(1), 37-50, doi:10.1080/19475701003625737.

Bookhagen, B., and D. W. Burbank (2006), Topography, relief, and TRMM-derived rainfall variations along the Himalaya, Geophys. Res. Lett., 33, L08405, doi:10.1029/2006GL026037.

Bookhagen, B., and D. W. Burbank (2010), Toward a complete himalayan hydrological budget: Spatiotemporal distribution of snowmelt and rainfall and their impact on river discharge, J. Geophys. Res., 115, F03019, doi:10.1029/2009JF001426.

Bookhagen, B., and M. R. Strecker (2012), Spatiotemporal trends in erosion rates across a pronounced rainfall gradient: Examples from the south-central Andes, Earth Planet. Sci. Lett., 327-328, 97-110.

Bookhagen, B., R. C. Thiede, and M. R. Strecker (2005), Abnormal monsoon years and their control on erosion and sediment flux in the high, arid northwest Himalaya, Earth Planet. Sci. Lett., 231(1-2), 131-146.

Boulton, G. S. (1979), Processes of glacier erosion on different substrata, J. Glaciol., 23, 15-38.

Boulton, G. S. (1996), Theory of glacial erosion, transport and deposition as a consequence of subglacial sediment deformation, J. Glaciol., 42, 43-62.

Braucher, R., E. T. Brown, D. L. Bourlès, and F. Colin (2003), In situ produced ${ }^{10} \mathrm{Be}$ measurements at great depths: Implications for production rates by fast muons, Earth Planet. Sci. Lett., 211(3-4), 251-258.

Braucher, R., S. Merchel, J. Borgomano, and D. L. Bourlès (2011), Production of cosmogenic radionuclides at great depth: A multi element approach, Earth Planet. Sci. Lett., 309(1-2), 1-9.

Brewer, I. D., D. W. Burbank, and K. V. Hodges (2006), Downstream development of a detrital cooling-age signal: Insights from ${ }^{40} \mathrm{Ar} /{ }^{39} \mathrm{Ar}$ muscovite thermochronology in the Nepalese Himalaya, Geol. Soc. Am. Spec. Pap., 398, 321-338.

Brocklehurst, S. H., and K. X. Whipple (2006), Assessing the relative efficiency of fluvial and glacial erosion through simulation of fluvial landscapes, Geomorphology, 75(3-4), 283-299, doi:10.1016/j.geomorph.2005.07.028.

Brocklehurst, S. H., and K. X. Whipple (2007), Response of glacial landscapes to spatial variations in rock uplift rate, J. Geophys. Res., 112, F02035, doi:10.1029/2006JF000667.

Brown, E. T., R. F. Stallard, M. C. Larsen, G. M. Raisbeck, and F. Yiou (1995), Denudation rates determined from the accumulation of in situproduced ${ }^{10} \mathrm{Be}$ in the Luquillo Experimental Forest, Puerto Rico, Earth Planet. Sci. Lett., 129(1-4), 193-202.

Burbank, D. W., A. E. Blythe, J. Putkonen, B. Pratt-Sitaula, E. Gabet, M. Oskin, A. Barros, and T. P. Ojha (2003), Decoupling of erosion and precipitation in the Himalayas, Nature, 426(6967), 652-655, doi:10.1038/ nature02187.

Cohen, D., T. S. Hooyer, N. R. Iverson, J. F. Thomason, and M. Jackson (2006), Role of transient water pressure in quarrying: A subglacial experiment using acoustic emissions, J. Geophys. Res., 111, F03006, doi:10.1029/ 2005JF000439.

Craddock, W. H., D. W. Burbank, B. Bookhagen, and E. J. Gabet (2007), Bedrock channel geometry along an orographic rainfall gradient in the upper Marsyandi River valley in central Nepal, J. Geophys. Res., 112, F03007, doi:10.1029/2006JF000589.

Delunel, R., P. A. van der Beek, J. Carcaillet, D. L. Bourlès, and P. G. Valla (2010), Frost-cracking control on catchment denudation rates: Insights from in situ produced ${ }^{10} \mathrm{Be}$ concentrations in stream sediments (Ecrins-Pelvoux massif, French Western Alps), Earth Planet. Sci. Lett., 293(1-2), 72-83.

DiBiase, R. A., K. X. Whipple, A. M. Heimsath, and W. B. Ouimet (2010), Landscape form and millennial erosion rates in the San Gabriel Mountains, CA, Earth Planet. Sci. Lett., 289(1-2), 134-144. 
Dowdeswell, J. A., D. Ottesen, and L. Rise (2010), Rates of sediment delivery from the Fennoscandian Ice Sheet through an ice age, Geology, 38(1), 3-6.

Duncan, C. C., A. J. Klein, J. G. Masek, and B. L. Isacks (1998), Comparison of Late Pleistocene and modern glacier extents in central Nepal based on digital elevation data and satellite imagery, Quat. Res., 49(3), 241-254, doi:doi:10.1006/qres.1998.1958.

Dunne, J., D. Elmore, and P. Muzikar (1999), Scaling factors for the rates of production of cosmogenic nuclides for geometric shielding and attenuation at depth on sloped surfaces, Geomorphology, 27(1-2), 3-11, doi:10.1016/S0169-555X(98)00086-5.

Egholm, D. L., S. B. Nielsen, V. K. Pedersen, and J. E. Lesemann (2009), Glacial effects limiting mountain height, Nature, 460(7257), 884-887, doi: 10.1038 /nature 08263 .

Foster, D., S. H. Brocklehurst, and R. L. Gawthorpe (2008), Small valley glaciers and the effectiveness of the glacial buzzsaw in the northern Basin and Range, USA, Geomorphology, 102(3-4), 624-639, doi:10.1016/j. geomorph.2008.06.009.

Foster, D., S. H. Brocklehurst, and R. L. Gawthorpe (2010), Glacial-topographic interactions in the Teton Range, Wyoming, J. Geophys. Res., 115, F01007, doi:10.1029/2008JF001135.

Gabet, E. J., D. W. Burbank, J. K. Putkonen, B. A. Pratt-Sitaula, and T. Ojha (2004a), Rainfall thresholds for landsliding in the Himalayas of Nepal, Geomorphology, 63(3-4), 131-143, doi:10.1016/j.geomorph.2004. 03.011 .

Gabet, E. J., B. A. Pratt-Sitaula, and D. W. Burbank (2004b), Climatic controls on hillslope angle and relief in the Himalayas, Geology, 32(7), 629-632.

Gabet, E. J., D. W. Burbank, B. Pratt-Sitaula, J. Putkonen, and B. Bookhagen (2008), Modern erosion rates in the High Himalayas of Nepal, Earth Planet. Sci. Lett., 267(3-4), 482-494, doi:10.1016/j.epsl.2007.11.059.

Gabet, E. J., D. Wolff-Boenisch, H. Langner, D. W. Burbank, and J. Putkonen (2010), Geomorphic and climatic controls on chemical weathering in the High Himalayas of Nepal, Geomorphology, 122(1-2), 205-210, doi:10.1016/j.geomorph.2010.06.016.

Garzanti, E., G. Vezzoli, S. Andò, J. Lavé, M. Attal, C. France-Lanord, and P. DeCelles (2007), Quantifying sand provenance and erosion (Marsyandi River, Nepal Himalaya), Earth Planet. Sci. Lett., 258(3-4), 500-515.

Gayer, E., S. Mukhopadhyay, and B. J. Meade (2008), Spatial variability of erosion rates inferred from the frequency distribution of cosmogenic ${ }^{3} \mathrm{He}$ in olivines from hawaiian river sediments, Earth Planet. Sci. Lett., 266(3-4), 303-315.

Godard, V., and D. W. Burbank (2011), Mechanical analysis of controls on strain partitioning in the Himalayas of central Nepal, J. Geophys. Res., 116, B10402, doi:10.1029/2011JB008272.

Godard, V., J. Lavé, and R. Cattin (2006), Numerical modelling of erosion processes in the Himalayas of Nepal: Effects of spatial variations of rock strength and precipitation, Geol. Soc. Spec. Publ., 253, 341-358, doi:10.1144/GSL.SP.2006.253.01.18.

Godard, V., R. Cattin, and J. Lavé (2009), Erosional control on the dynamics of low-convergence rate continental plateau margins, Geophys. J. Int., 179(2), 763-777, doi:10.1111/j.1365-246X.2009.04324.x.

Godard, V., J. Lavé, J. Carcaillet, R. Cattin, D. Bourlès, and J. Zhu (2010), Spatial distribution of denudation in Eastern Tibet and regressive erosion of plateau margins, Tectonophysics, 491, 253-274, doi:10.1016/ j.tecto.2009.10.026.

Gosse, J. C., and F. M. Phillips (2001), Terrestrial in situ cosmogenic nuclides: Theory and application, Quat. Sci. Rev., 20(14), 1475-1560, doi:10.1016/S0277-3791(00)00171-2.

Granger, D. E., J. W. Kirchner, and R. Finkel (1996), Spatially averaged long-term erosion rates measured from in situ-produced cosmogenic nuclides in alluvial sediment, J. Geol., 104(3), 249-257.

Hallet, B. (1979), A theoretical model of glacial abrasion, J. Glaciol., 23, 39-50.

Hallet, B. (1996), Glacial quarrying: A simple theoretical model, Ann. Glaciol., 22, 1-8.

Hallet, B., L. Hunter, and J. Bogen (1996), Rates of erosion and sediment evacuation by glaciers: A review of field data and their implications, Global Planet. Change, 12(1-4), 213-235, doi:10.1016/0921-8181(95) 00021-6.

Harper, J. T., and N. F. Humphrey (2003), High altitude Himalayan climate inferred from glacial ice flux, Geophys. Res. Lett., 30(14), 1764, doi:10.1029/2003GL017329.

Harrison, T. M., M. Grove, O. M. Lovera, and E. J. Catlos (1998), A model for the origin of Himalayan anatexis and inverted metamorphism, J. Geophys. Res., 103(B11), 27,017-27,032, doi:10.1029/98JB02468.

Heimsath, A. M., and R. McGlynn (2008), Quantifying periglacial erosion in the Nepal high Himalaya, Geomorphology, 97(1-2), 5-23.
Herman, F., and J. Braun (2006), Fluvial response to horizontal shortening and glaciations: A study in the Southern Alps of New Zealand, J. Geophys. Res., 111, F01008, doi:10.1029/2004JF000248.

Herman, F., and J. Braun (2008), Evolution of the glacial landscape of the Southern Alps of New Zealand: Insights from a glacial erosion model, J. Geophys. Res., 113, F02009, doi:10.1029/2007JF000807.

Herman, F., et al. (2010), Exhumation, crustal deformation, and thermal structure of the Nepal Himalaya derived from the inversion of thermochronological and thermobarometric data and modeling of the topography, J. Geophys. Res., 115, B06407, doi:10.1029/2008JB006126.

Hodges, K. V. (2000), Tectonics of the Himalaya and southern Tibet from two perspectives, Geol. Soc. Am. Bull., 112(3), 324-350.

Hodges, K. V., J. M. Hurtado, and K. X. Whipple (2001), Southward extrusion of Tibetan crust and its effect on Himalayan tectonics, Tectonics, 20(6), 799-809, doi:10.1029/2001TC001281.

Howard, A. D., W. E. Dietrich, and M. A. Seidl (1994), Modeling fluvial erosion on regional to continental scales, J. Geophys. Res., 99(B7), 13,971-13,986, doi:10.1029/94JB00744.

Humphrey, N., C. Raymond, and W. Harrison (1986), Discharges of turbid water during mini-surges of variegated glacier, Alaska, U.S.A., J. Glaciol., 32(111), 195-207.

Huntington, K. W., and K. V. Hodges (2006), A comparative study of detrital mineral and bedrock age-elevation methods for estimating erosion rates, J. Geophys. Res., 111, F03011, doi:10.1029/2005JF000454.

Huntington, K. W., A. E. Blythe, and K. V. Hodges (2006), Climate change and Late Pliocene acceleration of erosion in the Himalaya, Earth Planet. Sci. Lett., 252(1-2), 107-118, doi:10.1016/j.epsl.2006.09.031.

Jamieson, S. S. R., N. R. J. Hulton, and M. Hagdorn (2008), Modelling landscape evolution under ice sheets, Geomorphology, 97(1-2), 91-108, doi:10.1016/j.geomorph.2007.02.047.

Kirby, E., and K. X. Whipple (2001), Quantifying differential rock-uplift rates via stream profile analysis, Geology, 29(5), 415-418.

Kirby, E., K. X. Whipple, W. Tang, and Z. Chen (2003), Distribution of active rock uplift along the eastern margin of the Tibetan Plateau: Inferences from bedrock channel longitudinal profiles, J. Geophys. Res., 108(B4), 2217, doi:10.1029/2001JB000861.

Kirchner, J. W., R. C. Finkel, C. S. Riebe, D. E. Granger, J. L. Clayton, J. G. King, and W. F. Megahan (2001), Mountain erosion over $10 \mathrm{yr}, 10 \mathrm{ky}$, and 10 m.y. time scales, Geology, 29(7), 591-594.

Koppes, M., and B. Hallet (2006), Erosion rates during rapid deglaciation in Icy Bay, Alaska, J. Geophys. Res., 111, F02023, doi:10.1029/2005JF000349.

Koppes, M. N., and D. R. Montgomery (2009), The relative efficacy of fluvial and glacial erosion over modern to orogenic timescales, Nat. Geosci., 2(9), 644-647, doi:10.1038/ngeo616.

Lavé, J., and J. P. Avouac (2001), Fluvial incision and tectonic uplift across the Himalayas of central Nepal, J. Geophys. Res., 106(B11), 26,561-26,591, doi:10.1029/2001JB000359.

MacGregor, K. R., R. S. Anderson, and E. D. Waddington (2009), Numerical modeling of glacial erosion and headwall processes in alpine valleys, Geomorphology, 103(2), 189-204.

Molnar, P., and P. England (1990), Late Cenozoic uplift of mountain ranges and global climate change: Chicken or egg?, Nature, 346(6279), 29-34.

Nichols, K. K., P. R. Bierman, M. Caffee, R. Finkel, and J. Larsen (2005), Cosmogenically enabled sediment budgeting, Geology, 33(2), 133-136.

Niemi, N. A., M. Oskin, D. W. Burbank, A. M. Heimsath, and E. J. Gabet (2005), Effects of bedrock landslides on cosmogenically determined erosion rates, Earth Planet. Sci. Lett., 237(3-4), 480-498.

Norton, K. P., F. von Blanckenburg, and P. W. Kubik (2010), Cosmogenic nuclide-derived rates of diffusive and episodic erosion in the glacially sculpted upper Rhone Valley, Swiss Alps, Earth Surf. Processes Landforms, 35(6), 651-662.

O’Farrell, C. R., A. M. Heimsath, D. E. Lawson, L. M. Jorgensen, E. B. Evenson, G. Larson, and J. Denner (2009), Quantifying periglacial erosion: Insights on a glacial sediment budget, Matanuska Glacier, Alaska, Earth Surf. Processes Landforms, 34(15), 2008-2022.

Ouimet, W. B., K. X. Whipple, and D. E. Granger (2009), Beyond threshold hillslopes: Channel adjustment to base-level fall in tectonically active mountain ranges, Geology, 37(7), 579-582.

Perg, L. A., R. S. Anderson, and R. C. Finkel (2003), Use of cosmogenic radionuclides as a sediment tracer in the Santa Cruz littoral cell, California, United States, Geology, 31(4), 299-302.

Pratt, B., D. W. Burbank, A. Heimsath, and T. Ojha (2002), Impulsive alluviation during early Holocene strengthened monsoons, central Nepal Himalaya, Geology, 30(10), 911-914.

Pratt-Sitaula, B. (2005), Glaciers, climate, and topography in the Nepalese Himalaya, PhD thesis, Univ. of Calif., Santa Barbara.

Pratt-Sitaula, B., D. W. Burbank, A. Heimsath, and T. Ojha (2004), Landscape disequilibrium on 1000-10,000 year scales Marsyandi River, Nepal, 
central Himalaya, Geomorphology, 58(1-4), 223-241, doi:10.1016/ j.geomorph.2003.07.002.

Pratt-Sitaula, B., M. Garde, D. W. Burbank, M. Oskin, A. Heimsath, and E. Gabet (2007), Bedload-to-suspended load ratio and rapid bedrock incision from Himalayan landslide-dam lake record, Quat. Res., 68(1), 111-120, doi:10.1016/j.yqres.2007.03.005.

Pratt-Sitaula, B., D. W. Burbank, A. M. Heimsath, N. F. Humphrey, M. Oskin, and J. Putkonen (2011), Topographic control of asynchronous glacial advances: A case study from Annapurna, Nepal, Geophys. Res. Lett., 38, L24502, doi:10.1029/2011GL049940.

Rahaman, W., S. K. Singh, R. Sinha, and S. K. Tandon (2009), Climate control on erosion distribution over the Himalaya during the past $100 \mathrm{ka}$, Geology, 37(6), 559-562.

Raymo, M. E., and W. F. Ruddiman (1992), Tectonic forcing of late Cenozoic climate, Nature, 359(6391), 117-122.

Rea, B. R., and B. Whalley (1994), Subglacial observations from Øksfjordjøkelen, north Norway, Earth Surf. Processes Landforms, 19(7), 659-673.

Riihimaki, C. A., K. R. MacGregor, R. S. Anderson, S. P. Anderson, and M. G. Loso (2005), Sediment evacuation and glacial erosion rates at a small alpine glacier, J. Geophys. Res., 110, F03003, doi:10.1029/ 2004JF000189.

Ruhl, K. W., and K. V. Hodges (2005), The use of detrital mineral cooling ages to evaluate steady state assumptions in active orogens: An example from the central Nepalese Himalaya, Tectonics, 24, TC4015, doi:10.1029/ 2004TC001712.

Safran, E. B., P. R. Bierman, R. Aalto, T. Dunne, K. X. Whipple, and M. Caffee (2005), Erosion rates driven by channel network incision in the Bolivian Andes, Earth Surf. Processes Landforms, 30(8), 1007-1024.

Schaller, M., F. von Blanckenburg, N. Hovius, and P. W. Kubik (2001), Large-scale erosion rates from in situ-produced cosmogenic nuclides in European river sediments, Earth Planet. Sci. Lett., 188(3-4), 441-458.

Scherler, D., B. Bookhagen, and M. R. Strecker (2011a), Hillslope-glacier coupling: The interplay of topography and glacial dynamics in High Asia, J. Geophys. Res., 116, F02019, doi:10.1029/2010JF001751.

Scherler, D., B. Bookhagen, and M. R. Strecker (2011b), Spatially variable response of Himalayan glaciers to climate change affected by debris cover, Nat. Geosci., 4, 156-159, doi:10.1038/ngeo1068.

Searle, M. P., and L. Godin (2003), The South Tibetan Detachment and the Manaslu Leucogranite: A structural reinterpretation and restoration of the Annapurna-Manaslu Himalaya, Nepal, J. Geol., 111, 505-523, doi:10.1086/376763.

Seong, Y. B., L. A. Owen, M. W. Caffee, U. Kamp, M. P. Bishop, A. Bush, L. Copland, and J. F. Shroder (2009), Rates of basin-wide rockwall retreat in the $\mathrm{K} 2$ region of the Central Karakoram defined by terrestrial cosmogenic nuclide ${ }^{10} \mathrm{Be}$, Geomorphology, 107(3-4), 254-262, doi:10.1016/ j.geomorph.2008.12.014.

Siame, L. L., J. Angelier, R. F. Chen, V. Godard, F. Derrieux, D. L. Bourles, R. Braucher, K. J. Chang, H. T. Chu, and J. C. Lee (2011), Erosion rates in an active orogene (NE-Taiwan): A confrontation of cosmogenic measurements with river suspended loads., Quat. Geochronology, 6(2), 246-260 doi:10.1016/j.quageo.2010.11.003.

Sklar, L. S., and W. E. Dietrich (2001), Sediment and rock strength controls on river incision into bedrock, Geology, 29(12), 1087-1090.

Small, R. J., I. R. Beecroft, and D. M. Stirling (1984), Rates of deposition on lateral moraine embankments, Glacier de Tsidjiore Nouve, Valais, Switzerland, J. Glaciol., 30(106), 275-281.

Staiger, J. W., J. Gosse, E. C. Little, D. J. Utting, R. Finkel, J. V. Johnson, and J. Fastook (2006), Glacial erosion and sediment dispersion from detrital cosmogenic nuclide analyses of till, Quat. Geochronology, 1(1), 29-42.
Stone, J. O. (2000), Air pressure and cosmogenic isotope production, J. Geophys. Res., 105(B10), 23,753-23,759, doi:10.1029/2000JB900181.

Streit, R., D. W. Burbank, and J. K. Hourigan (2011), Coupling between exhumation and precipitation across the Central Nepalese Himalaya: Evidence from apatite and zircon (U-Th)/He analyses, Abstract EP23C0760 presented at 2011 Fall Meeting, AGU, San Francisco, Calif, 3-7 Dec.

Thiede, R. C., B. Bookhagen, J. R. Arrowsmith, E. R. Sobel, and M. R. Strecker (2004), Climatic control on rapid exhumation along the Southern Himalayan Front, Earth Planet. Sci. Lett., 222(3-4), 791-806.

Thomson, S. N., M. T. Brandon, J. H. Tomkin, P. W. Reiners, C. Vasquez, and N. J. Wilson (2010), Glaciation as a destructive and constructive control on mountain building, Nature, 467(7313), 313-317.

Tomkin, J. (2007), Coupling glacial erosion and tectonics at active orogens: A numerical modeling study, J. Geophys. Res., 112, F02015, doi:10.1029/ 2005JF000332.

Tomkin, J. H., and G. H. Roe (2007), Climate and tectonic controls on glaciated critical-taper orogens, Earth Planet. Sci. Lett., 262(3-4), 385-397.

Tucker, G. E., and K. X. Whipple (2002), Topographic outcomes predicted by stream erosion models: Sensitivity analysis and intermodel comparison, J. Geophys. Res., 107(B9), 2179, doi:10.1029/2001JB000162.

Vance, D., M. Bickle, S. Ivy-Ochs, and P. W. Kubik (2003), Erosion and exhumation in the Himalaya from cosmogenic isotope inventories of river sediment, Earth Planet. Sci. Lett., 206(3-4), 273-288.

von Blanckenburg, F. (2005), The control mechanisms of erosion and weathering at basin scale from cosmogenic nuclides in river sediment, Earth Planet. Sci. Lett., 237(3-4), 462-479.

Ward, D. J., and R. S. Anderson (2011), The use of ablation-dominated medial moraines as samplers for ${ }^{10} \mathrm{Be}$-derived erosion rates of glacier valley walls, Kichatna Mountains, AK, Earth Surf. Processes Landforms, 36 (4), 495-512.

Weidinger, J. T. (2006), Predesign, failure and displacement mechanisms of large rockslides in the Annapurna Himalayas, Nepal, Eng. Geol., 83(1-3), 201-216, doi:10.1016/j.enggeo.2005.06.032.

Whipp, D. M., T. A. Ehlers, A. E. Blythe, K. W. Huntington, K. V. Hodges, and D. W. Burbank (2007), Plio-Quaternary exhumation history of the central Nepalese Himalaya: 2. Thermokinematic and thermochronometer age prediction model, Tectonics, 26, TC3003, doi:10.1029/2006TC001991.

Whipple, K. X., and B. J. Meade (2006), Orogen response to changes in climatic and tectonic forcing, Earth Planet. Sci. Lett., 243(1-2), 218-228.

Willett, S. (1999), Orogeny and orography: The effects of erosion on the structure of mountain belts, J. Geophys. Res., 104(B12), 28,957-28,981, doi:10.1029/1999JB900248.

Wittmann, H., F. von Blanckenburg, T. Kruesmann, K. P. Norton, and P. W. Kubik (2007), Relation between rock uplift and denudation from cosmogenic nuclides in river sediment in the Central Alps of Switzerland, J. Geophys. Res., 112, F04010, doi:10.1029/2006JF000729.

Wobus, C. W., K. V. Hodges, and K. X. Whipple (2003), Has focused denudation sustained active thrusting at the Himalayan topographic front?, Geology, 31(10), 861-864.

Yanites, B. J., G. E. Tucker, and R. S. Anderson (2009), Numerical and analytical models of cosmogenic radionuclide dynamics in landslidedominated drainage basins, J. Geophys. Res., 114, F01007, doi:10.1029/ 2008JF001088.

Yin, A. (2006), Cenozoic tectonic evolution of the Himalayan orogen as constrained by along-strike variation of structural geometry, exhumation history, and foreland sedimentation, Earth Sci. Rev., 76(1-2), 1-131, doi:10.1016/j.earscirev.2005.05.004.

Zech, R., M. Zech, P. W. Kubik, K. Kharki, and W. Zech (2009), Deglaciation and landscape history around Annapurna, Nepal, based on ${ }^{10} \mathrm{Be}$ surface exposure dating, Quat. Sci. Rev., 28(11-12), 1106-1118, doi:10.1016/ j.quascirev.2008.11.013. 